\title{
Compacting local protein folds with a "Hybrid Protein Model"
}

\author{
A.G. de Brevern ${ }^{\dagger}$ and S. Hazout \\ Equipe de Bioinformatique Génomique et Moléculaire, INSERM U436, \\ Université Paris 7, case 7113, \\ 2, place Jussieu, 75251 Paris cedex 05, France. \\ †: Correspondence to: Alexander de Brevern, \\ E-mail: debrevern@urbb.jussieu.fr \\ phone: 33 - 1 - 44277731 fax: 33 - 1- 43263830
}

short title: Compacting local protein folds.

key words: protein block, unsupervised classifier, fold similarity.

September 11, 2000 


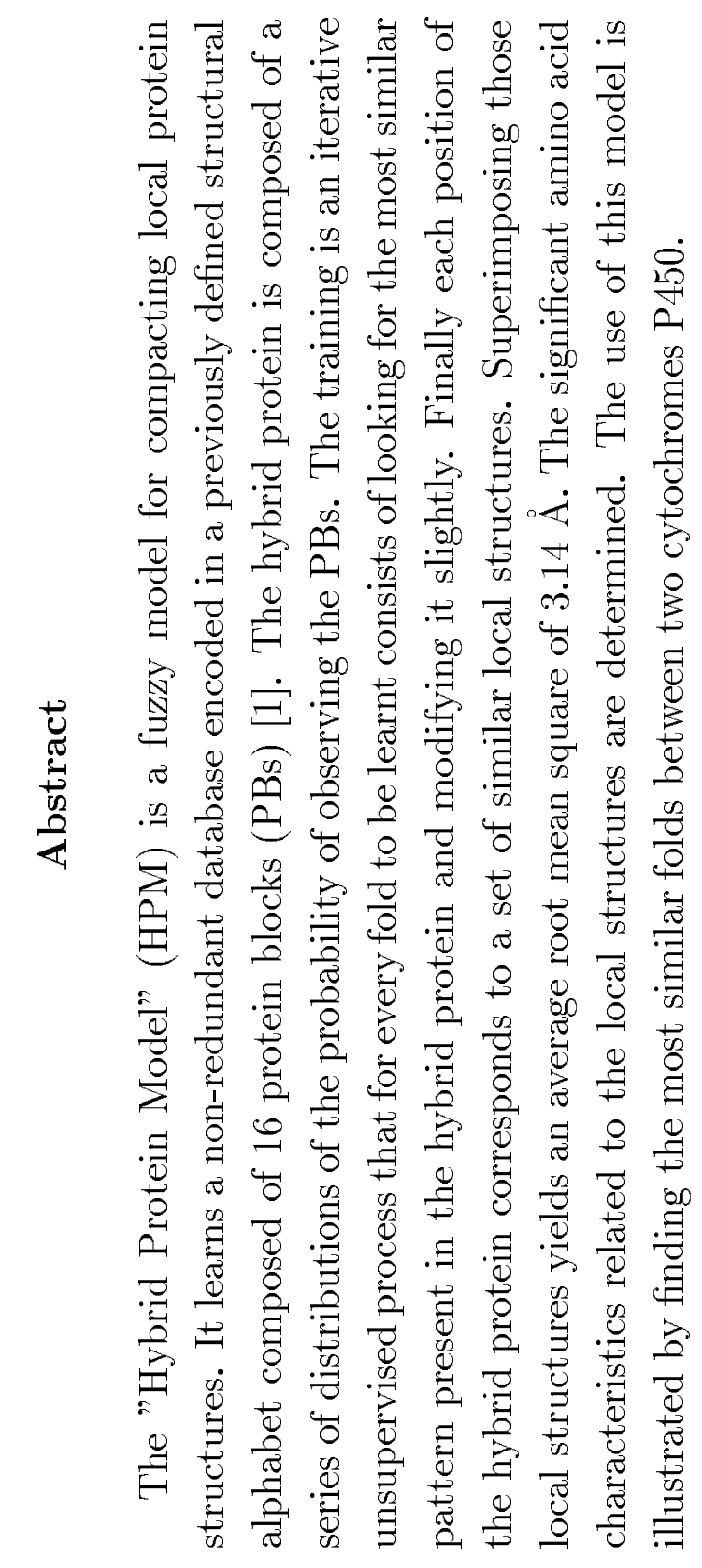




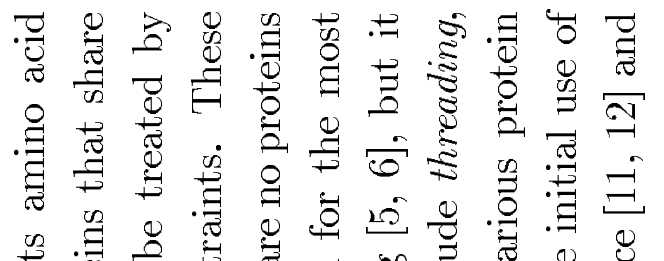

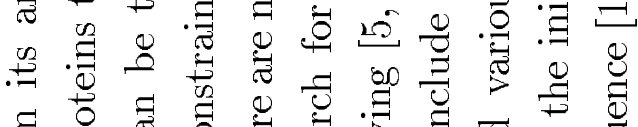

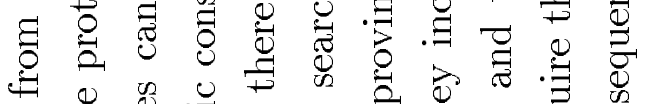

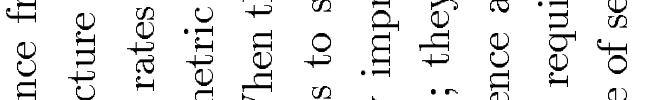

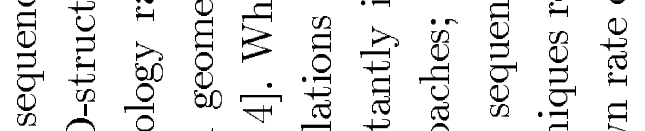

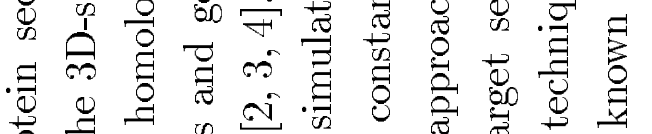

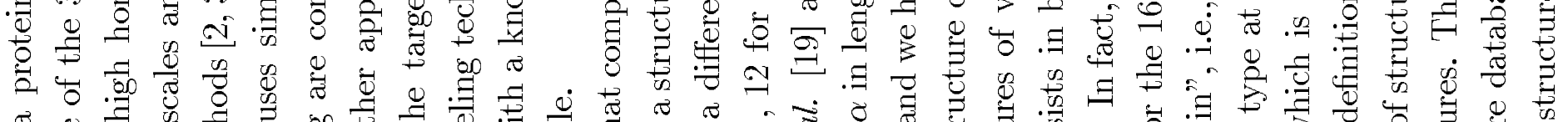

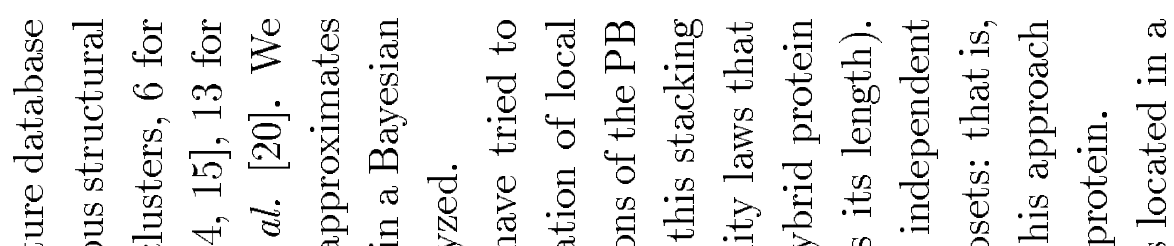

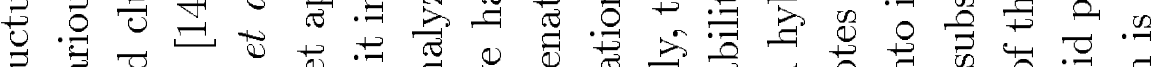

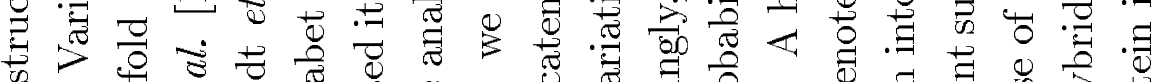

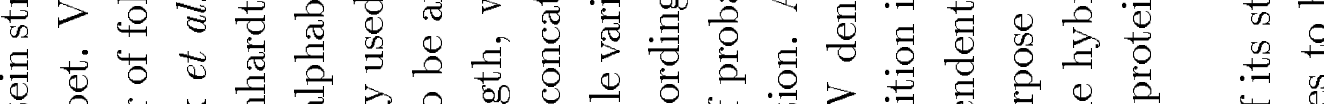

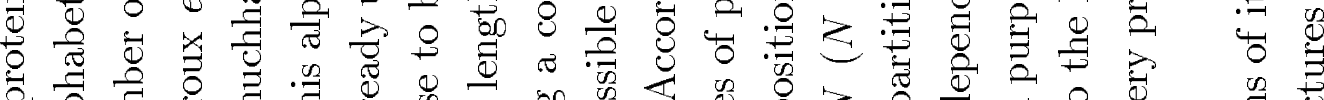

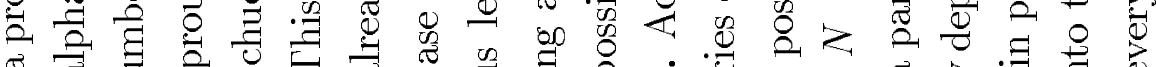

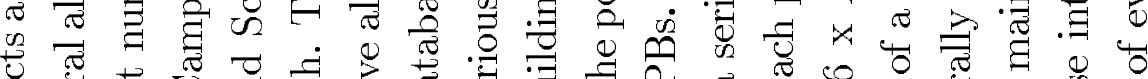

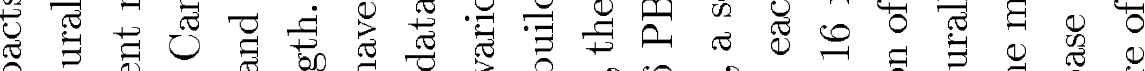

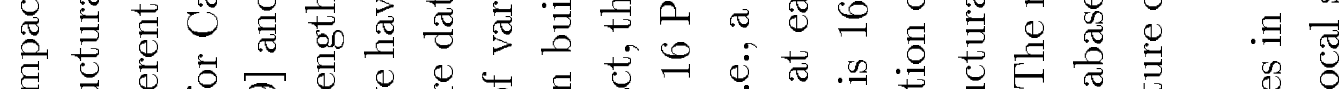

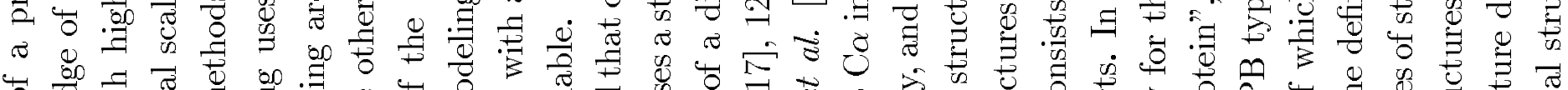

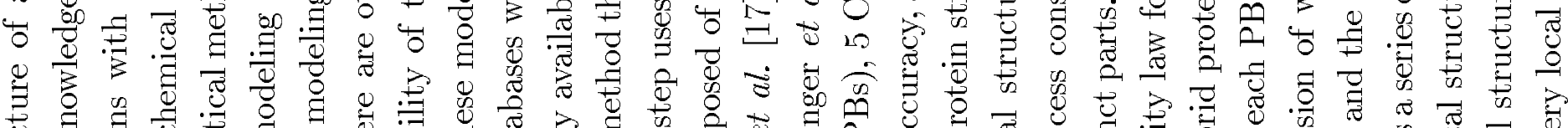

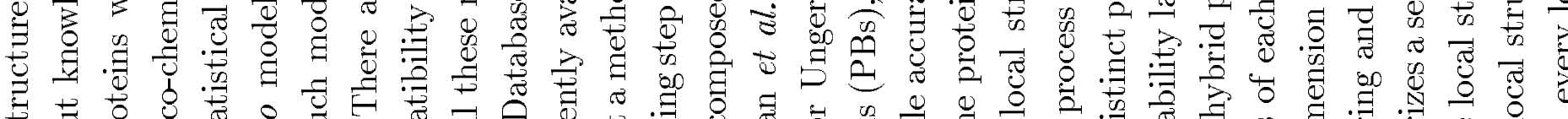

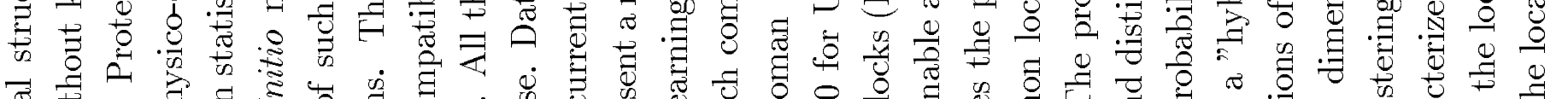

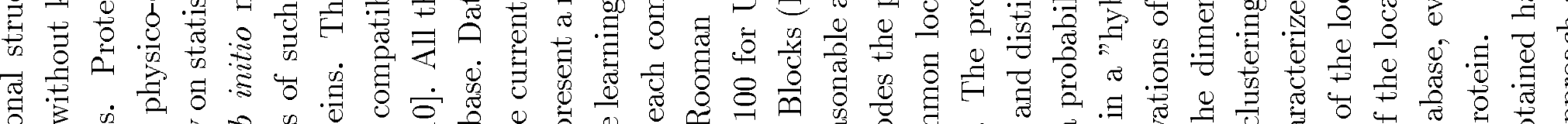

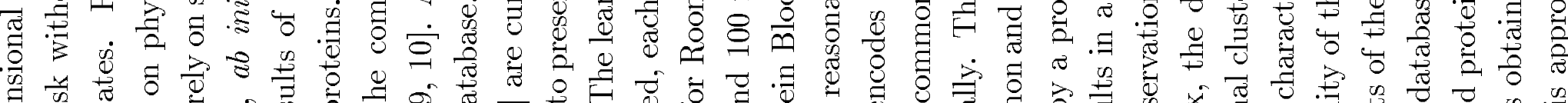

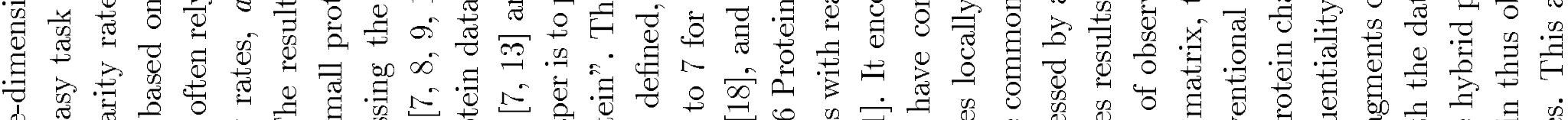

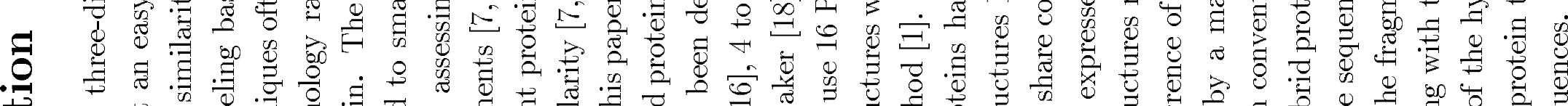

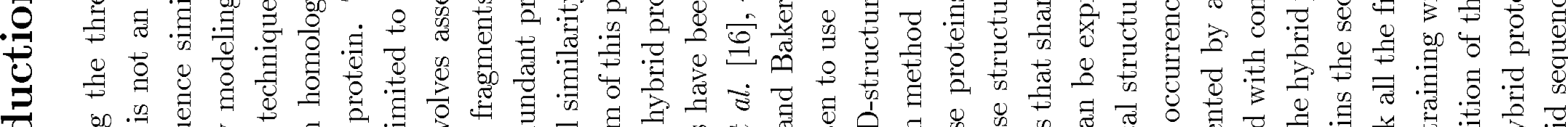

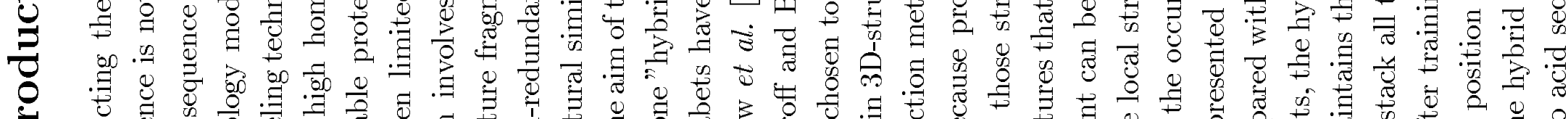

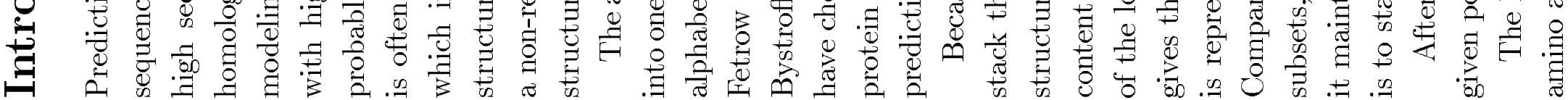




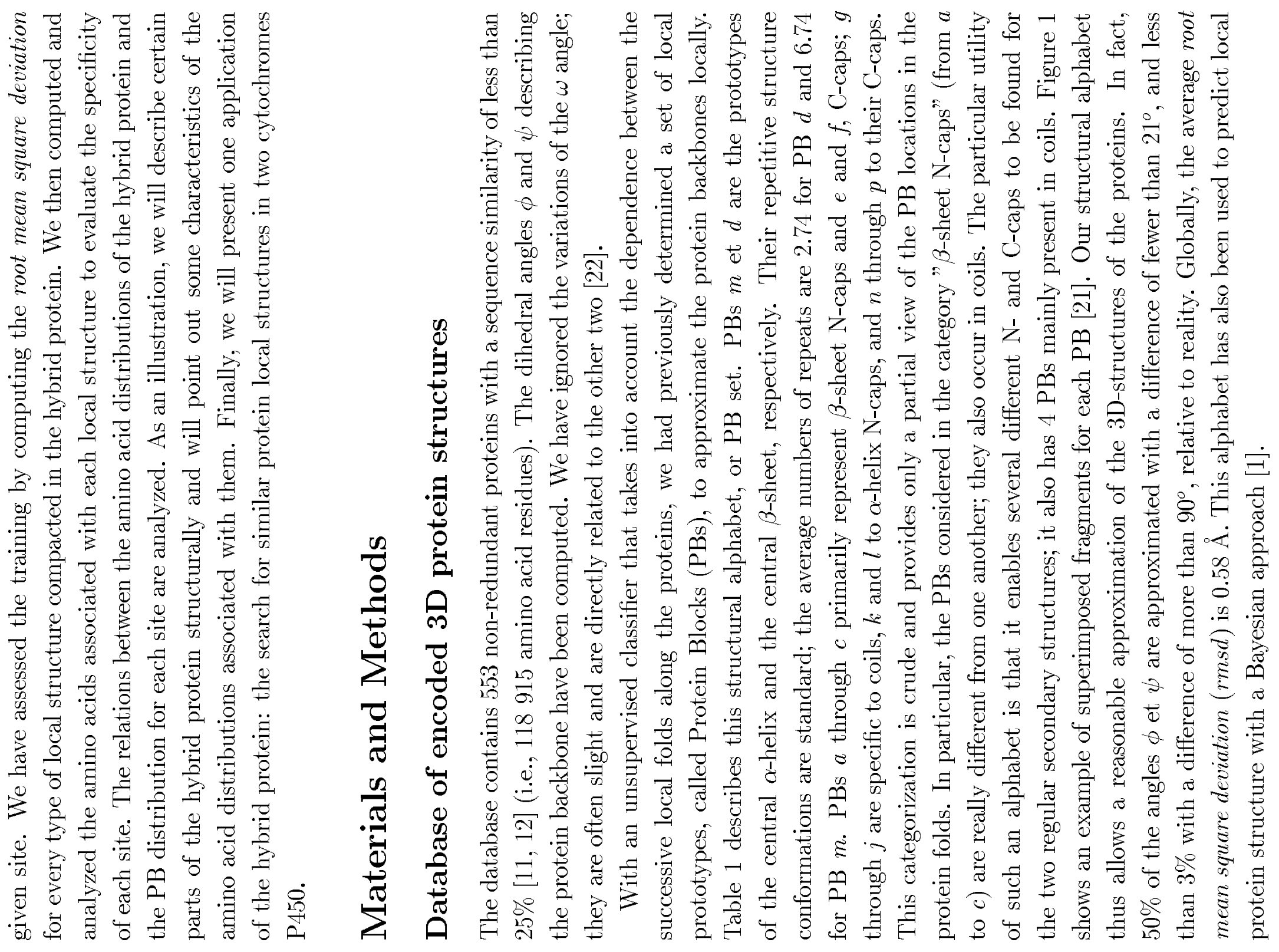




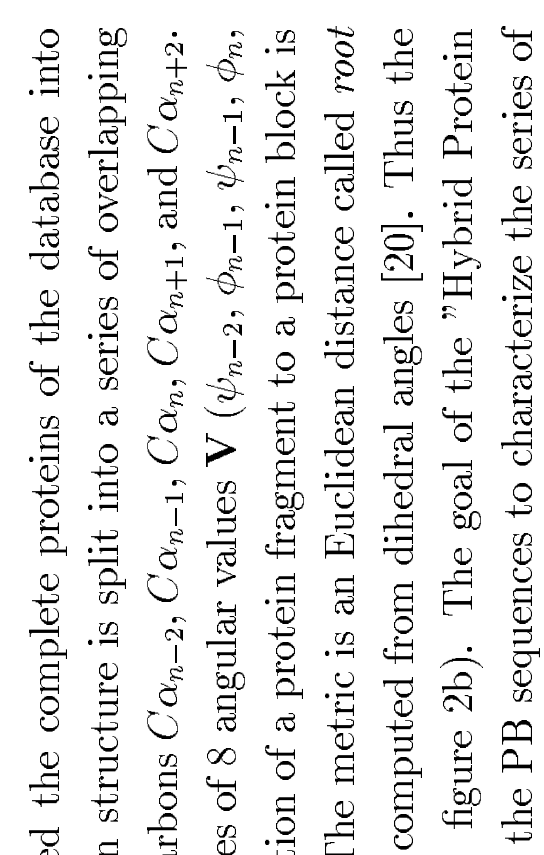

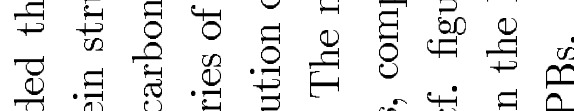

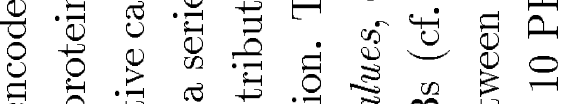
वे

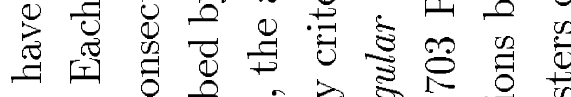

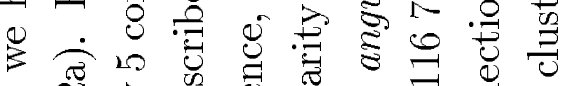

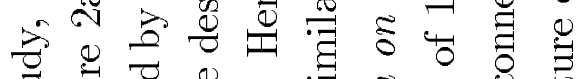

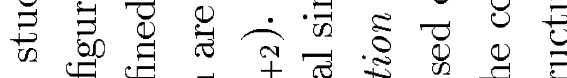

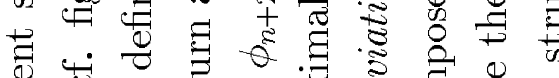
过曹 ㄹ.

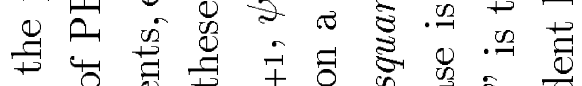

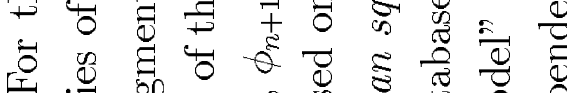

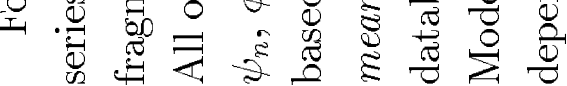

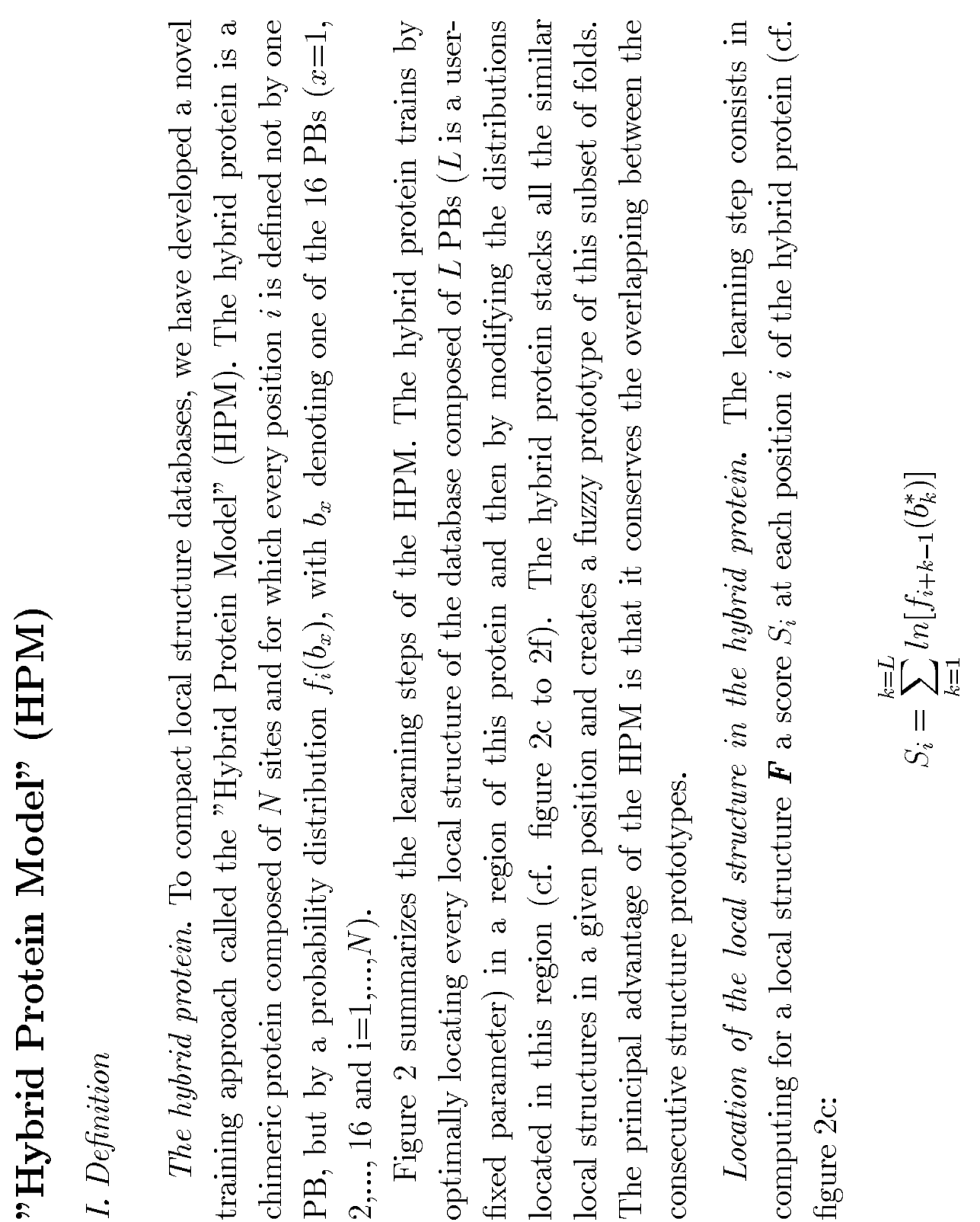

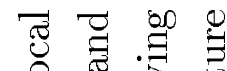

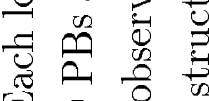
되 은ㅎㅇ 증 जी ㄴ II $\leqslant$ o 回焉 호의

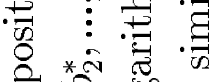
의 시웡 的 范过 $\Phi$ i

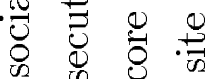
: 过总总

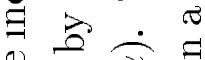
老 㐘者 约 \& $E$ 过 总芯芯 产总号要 


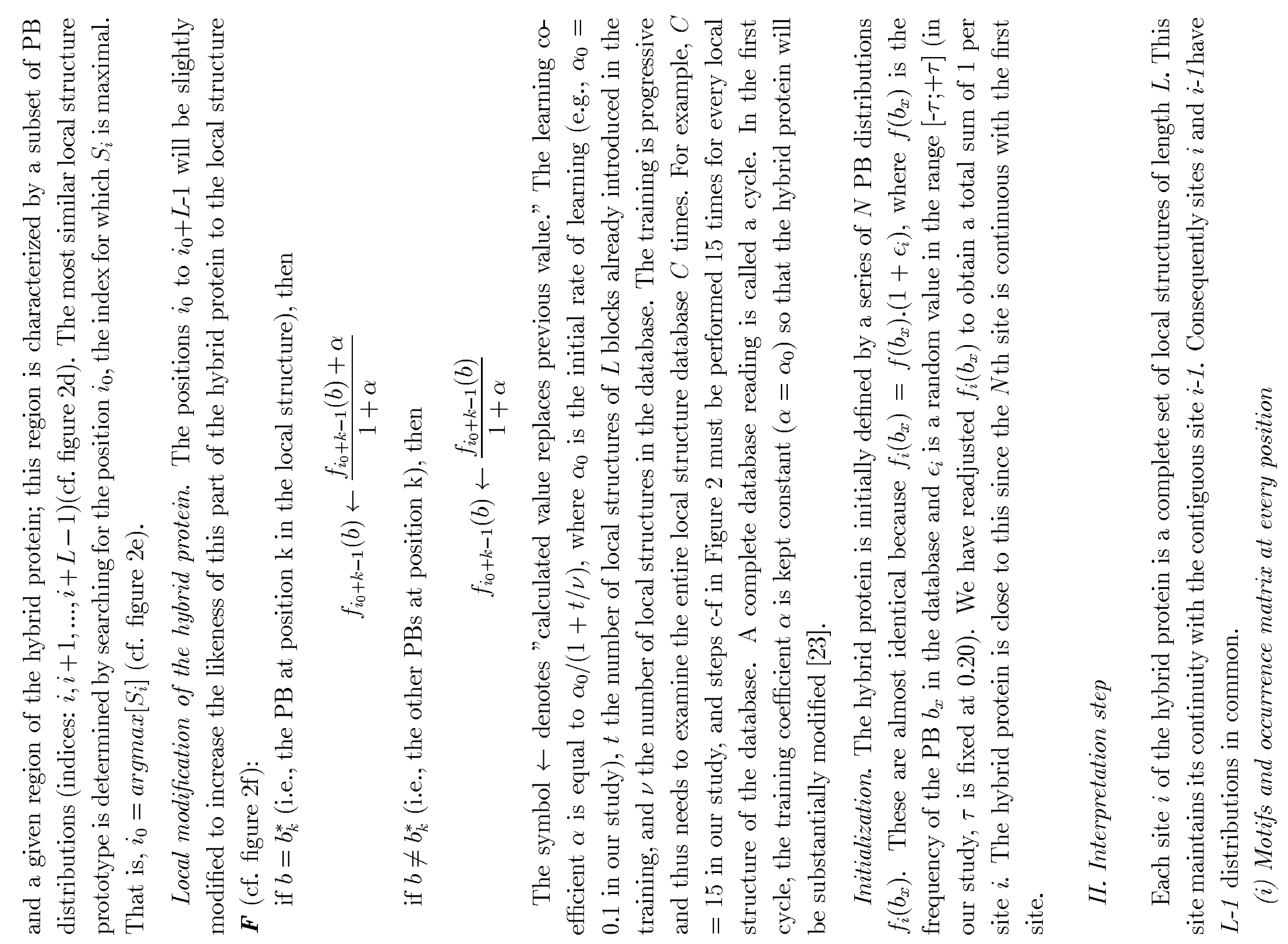




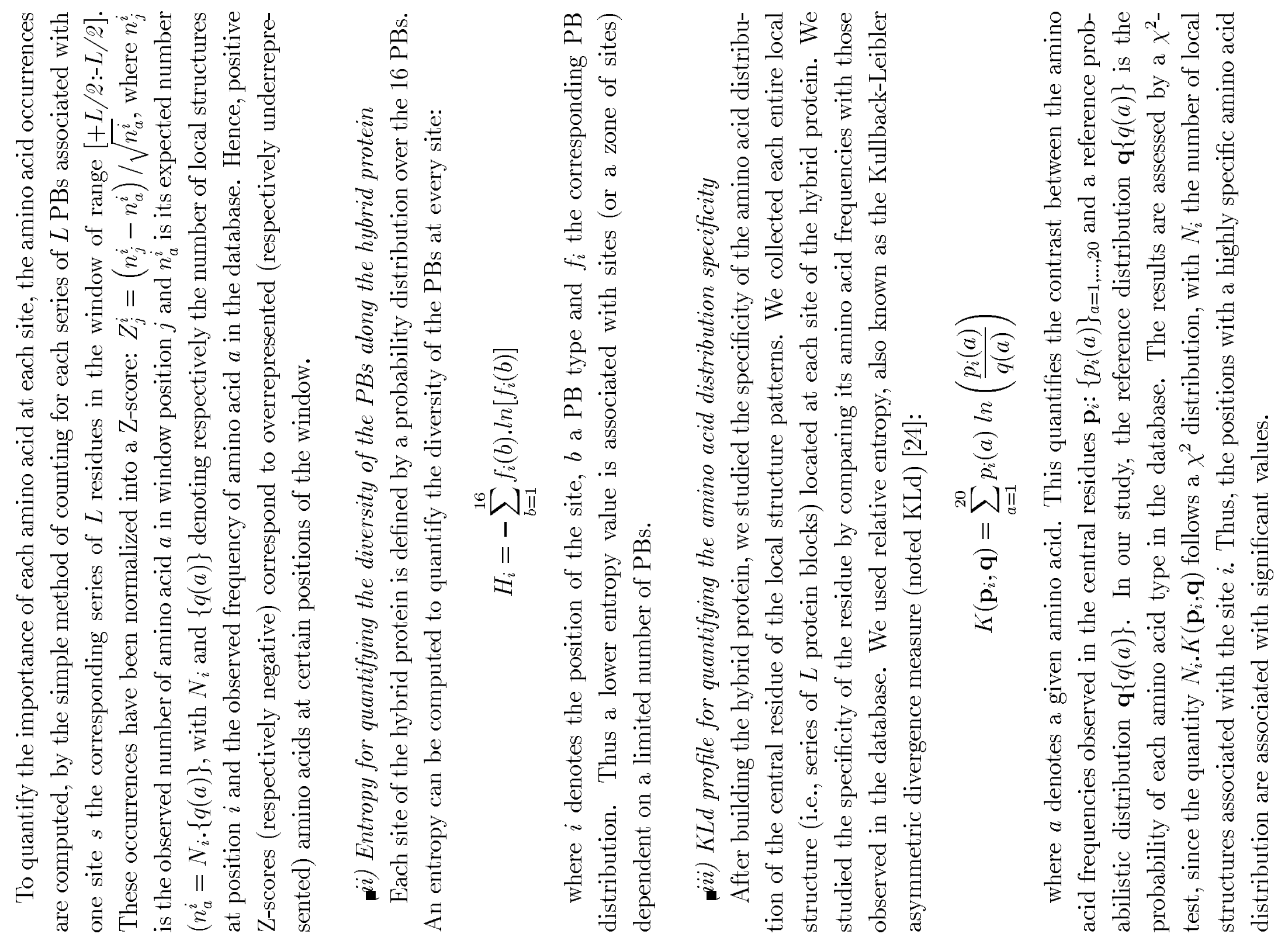




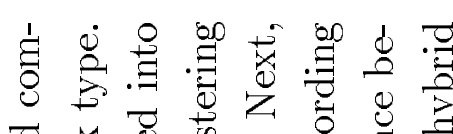

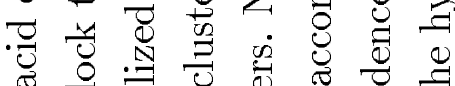

응

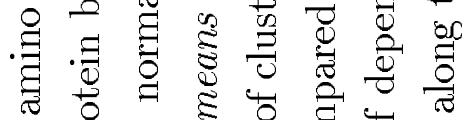

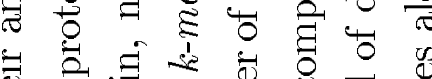

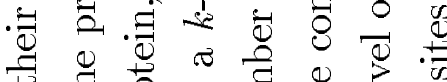

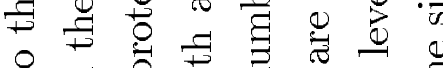
of of

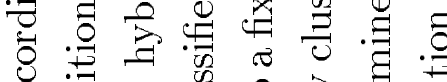

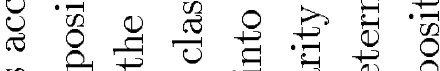

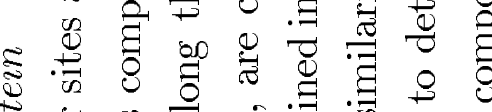

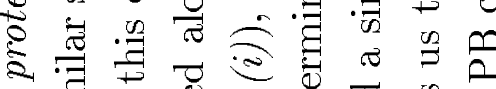

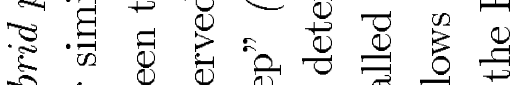

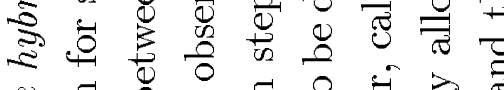

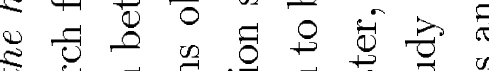

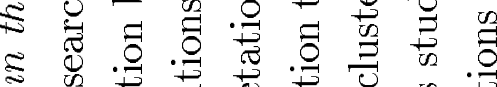

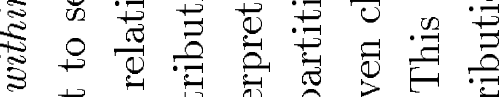

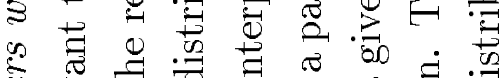

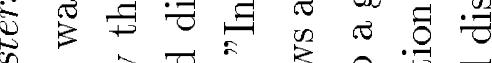

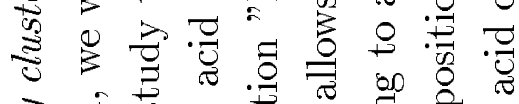

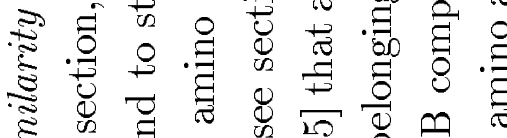

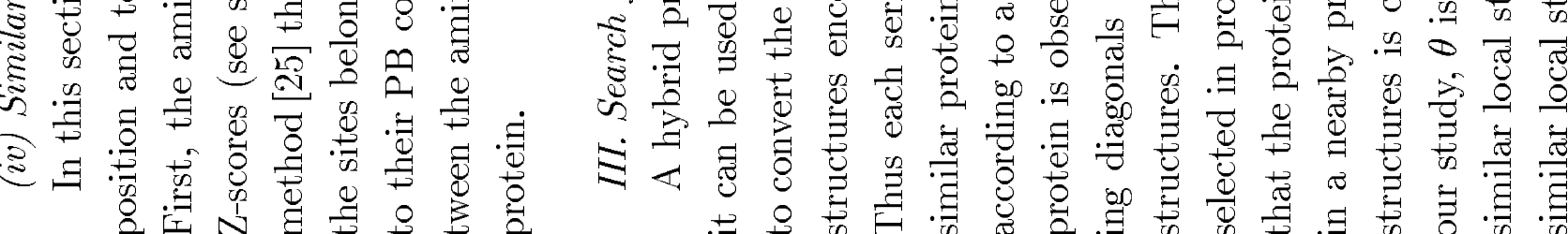

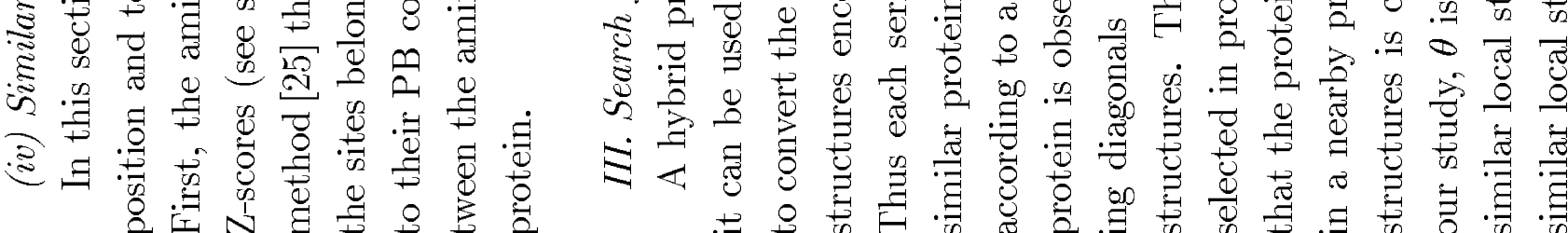

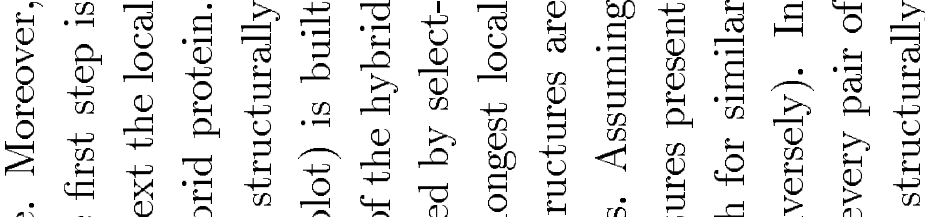

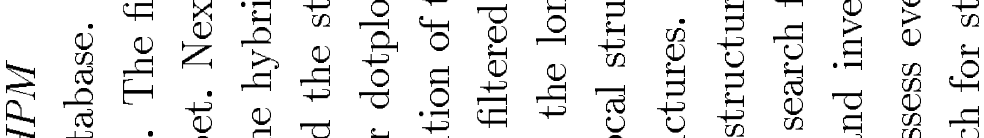

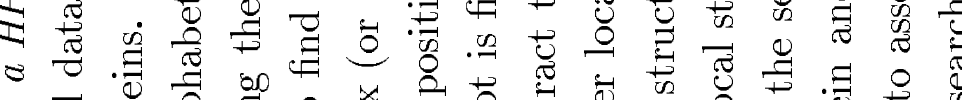

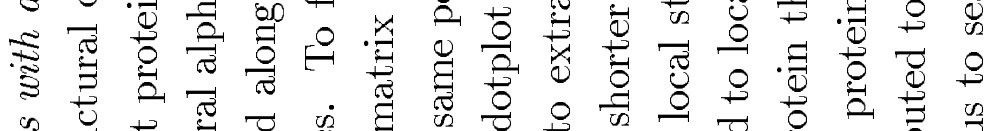

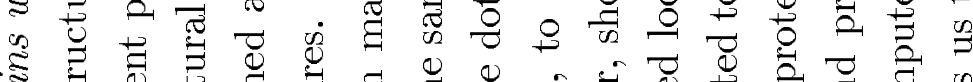

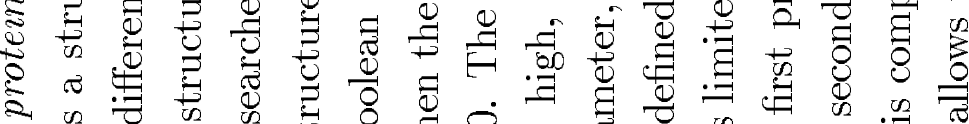

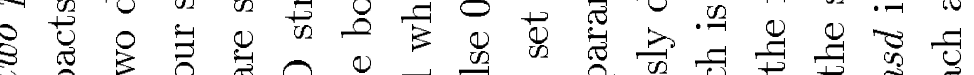

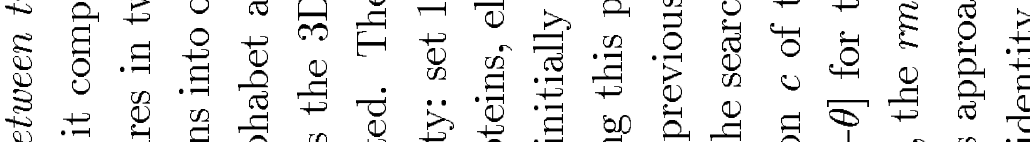

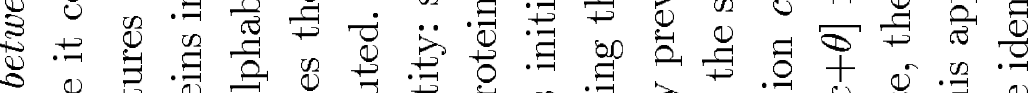

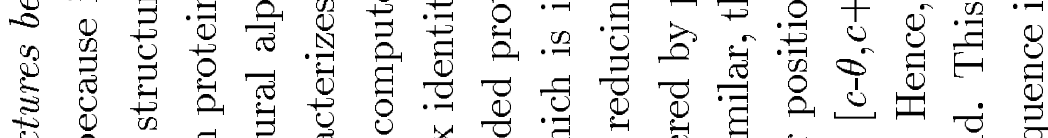

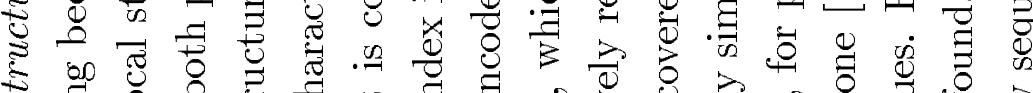

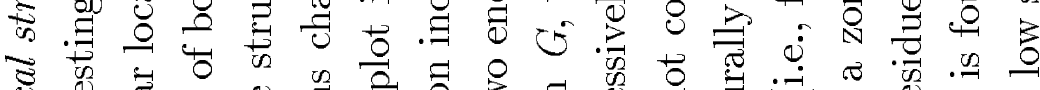

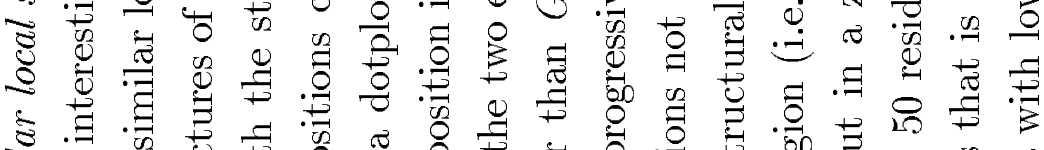

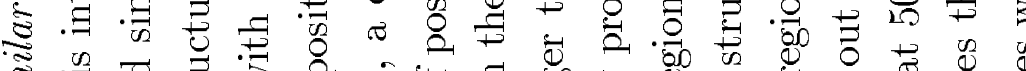

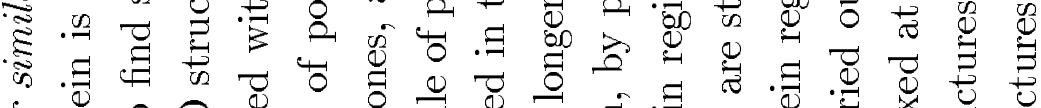

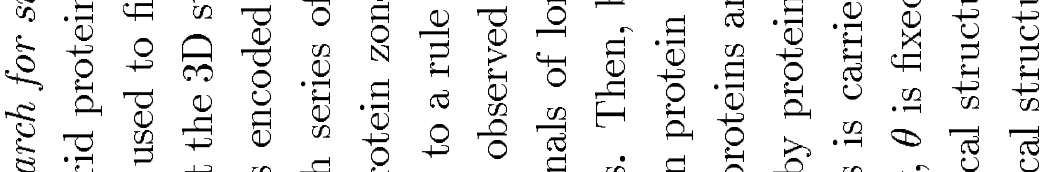

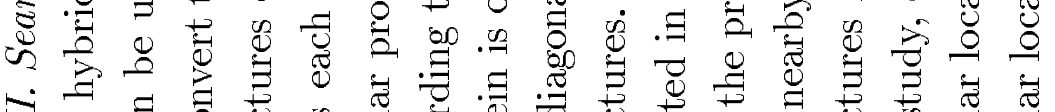

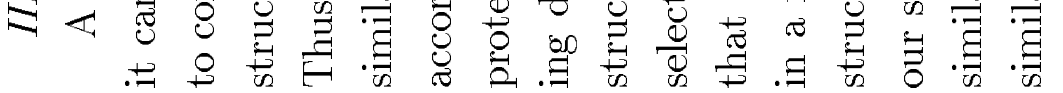

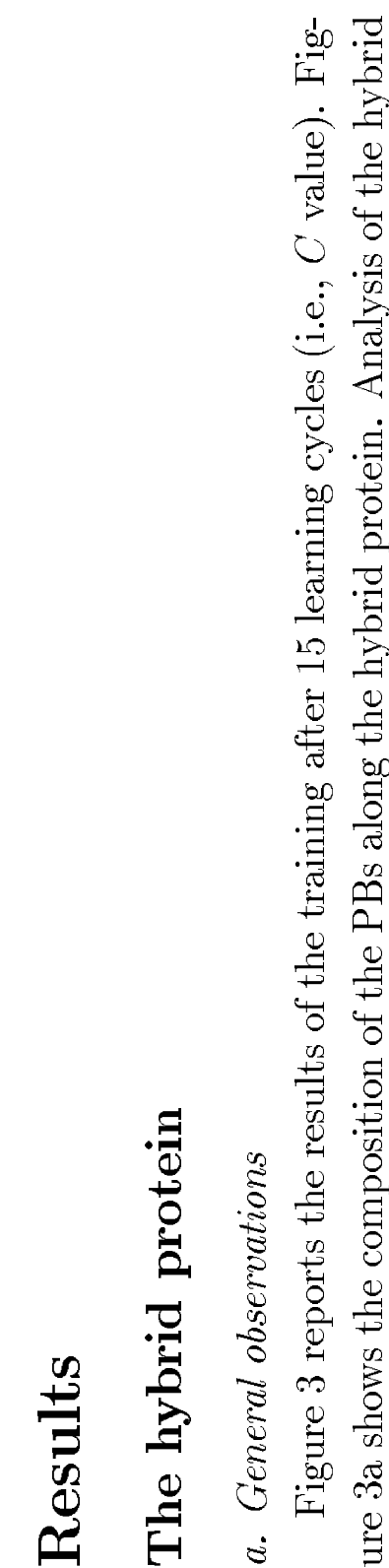



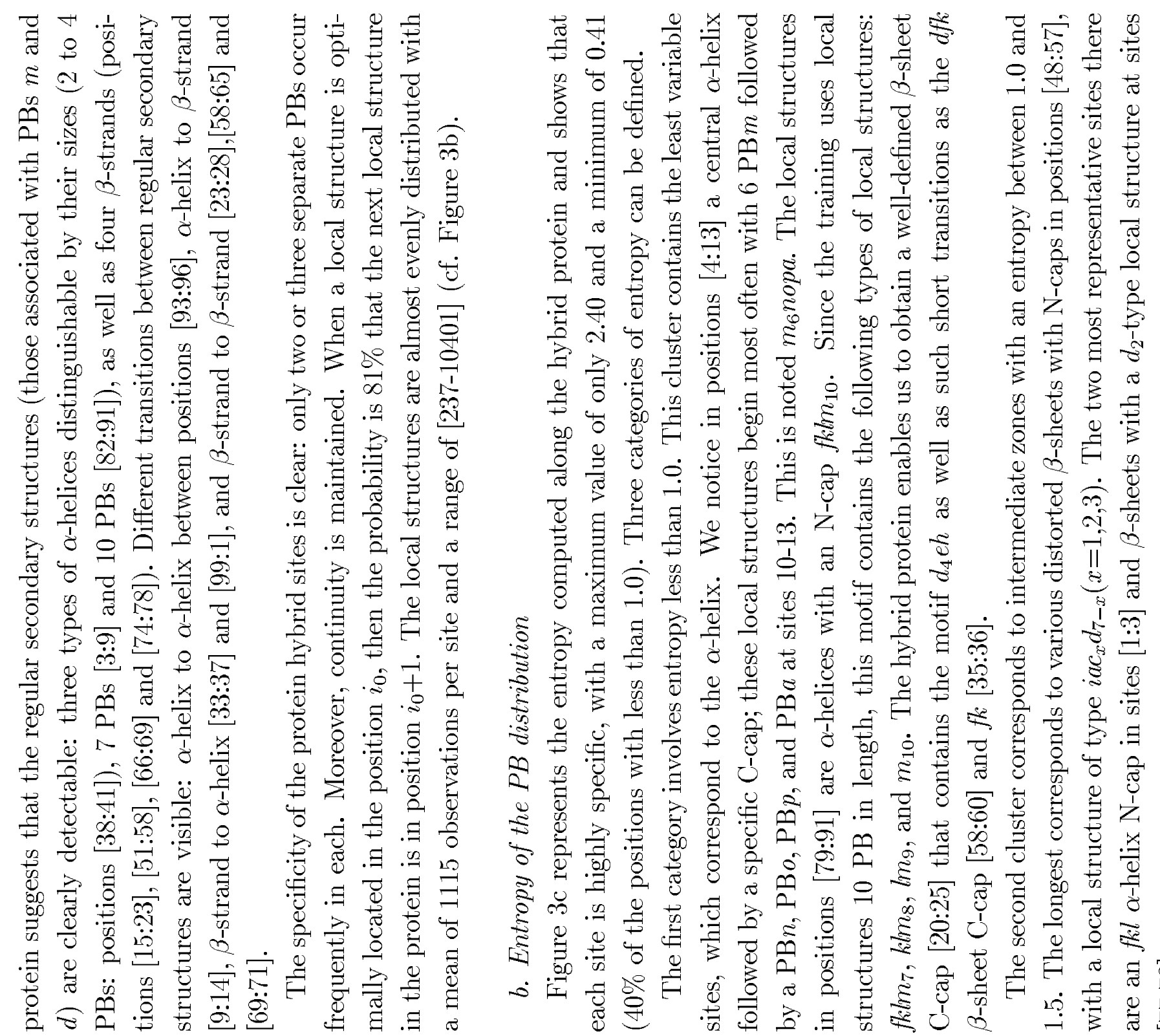

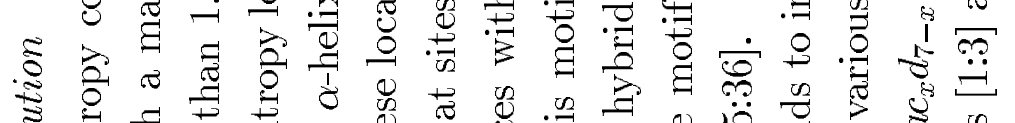

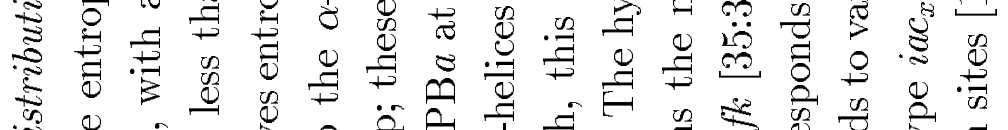

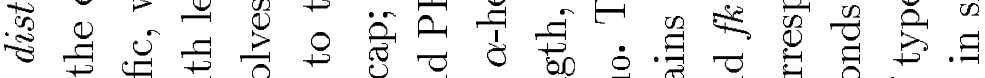

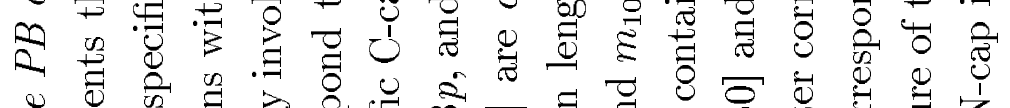

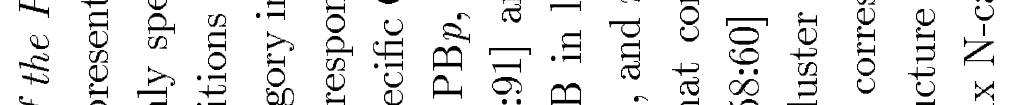

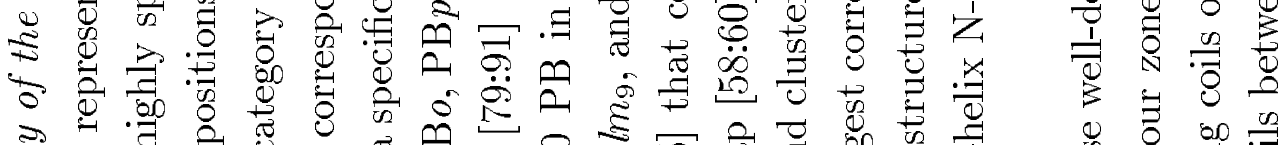

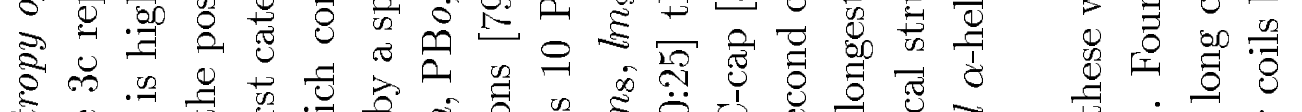

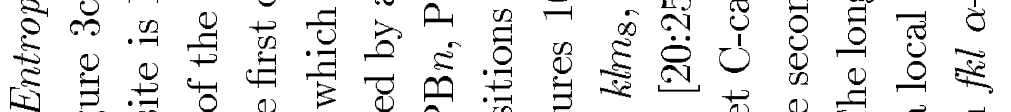

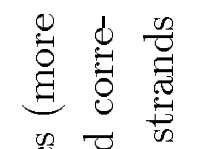

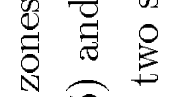
家尔

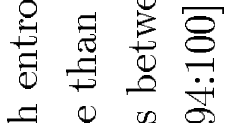
范范 寻击吉 क व्व 䒠老嵒 可

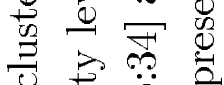

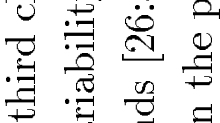
㱐 की

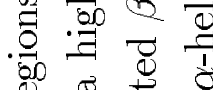

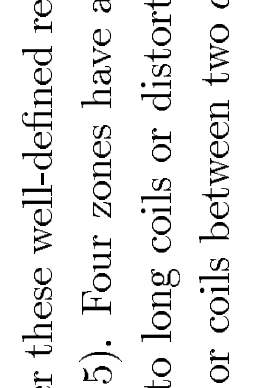

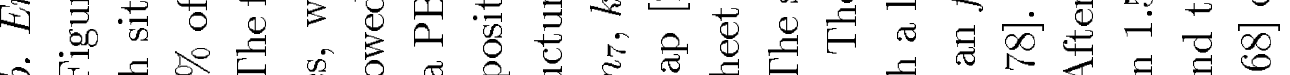

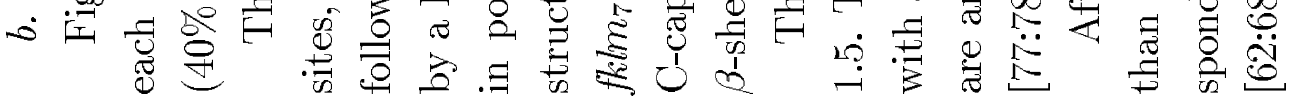




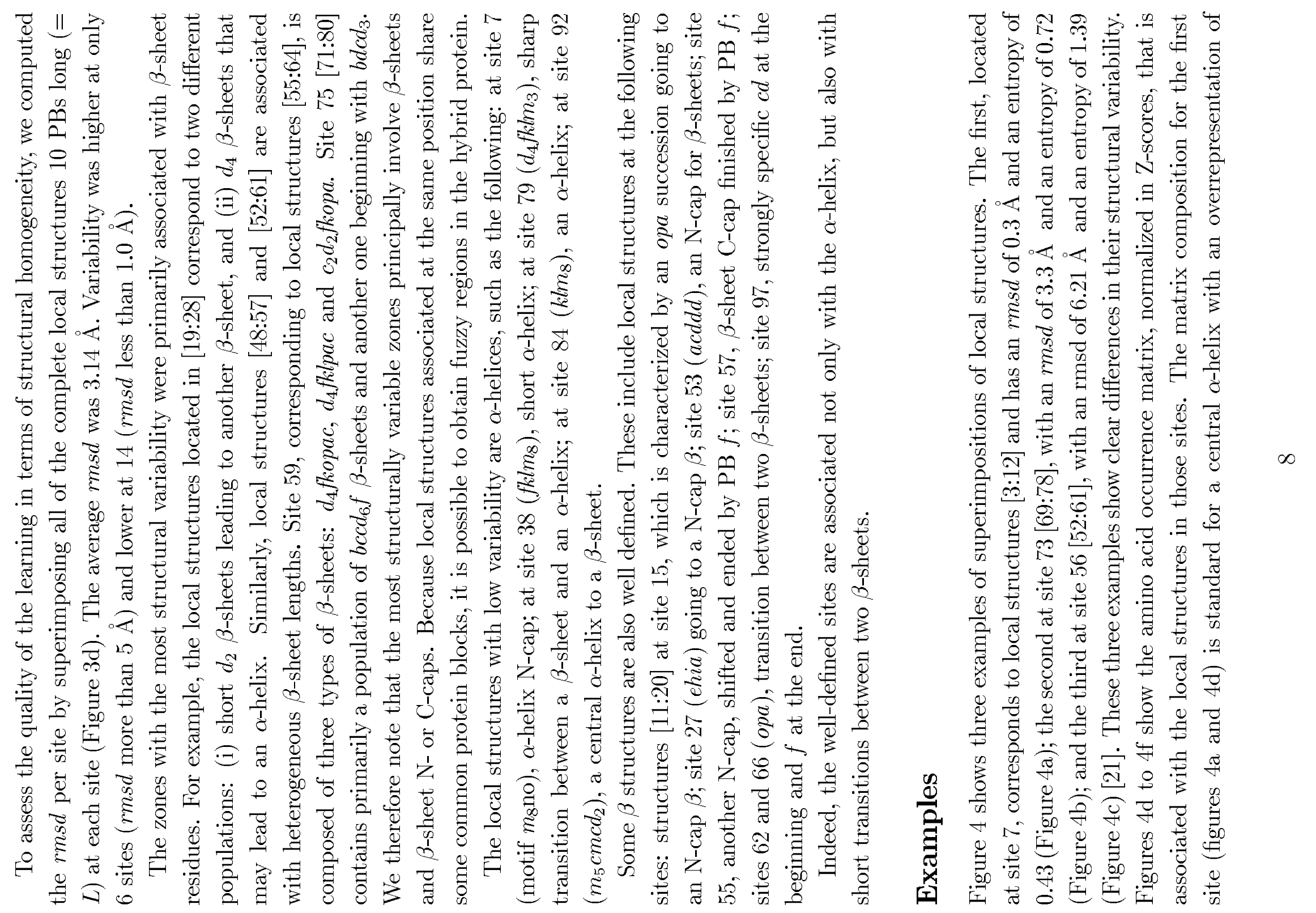




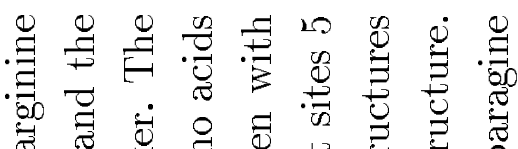

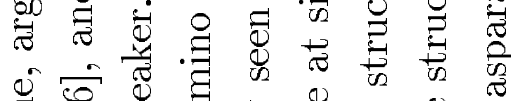

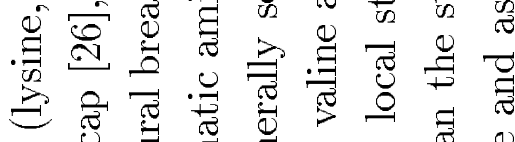

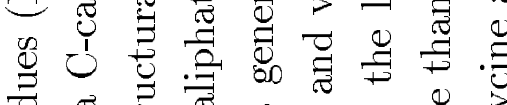

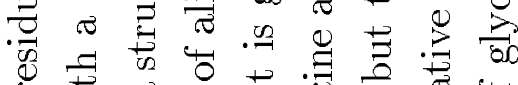

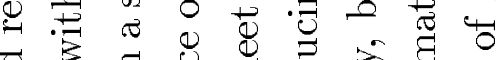
क्ष

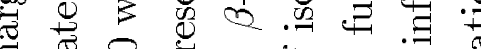

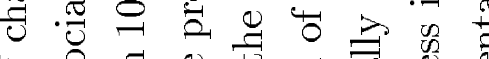

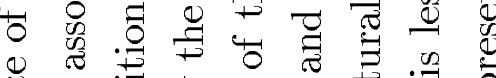

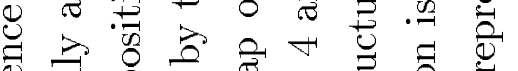

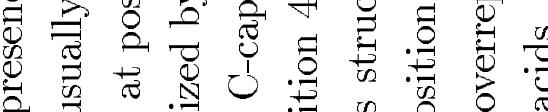

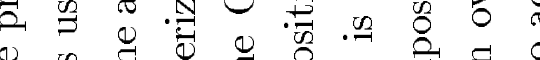
‡.

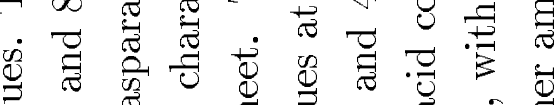

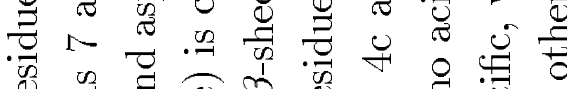

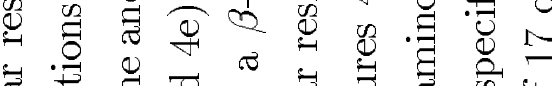

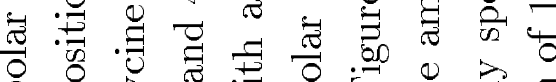

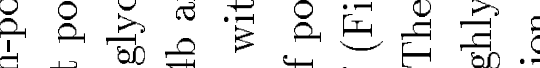

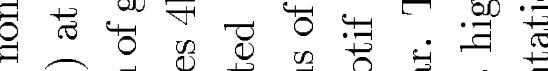
焉

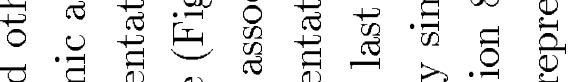

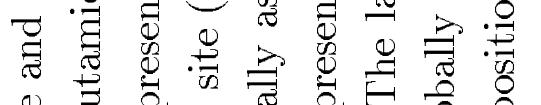

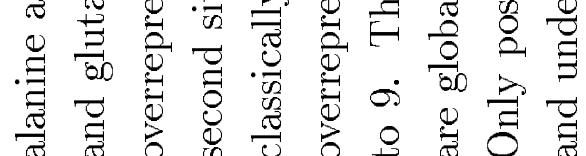

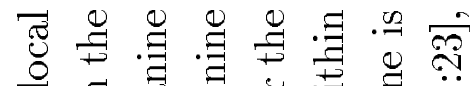

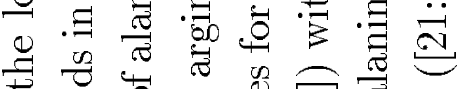

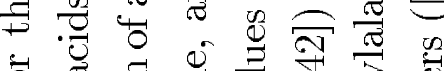

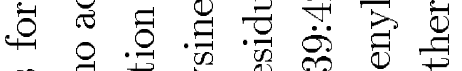

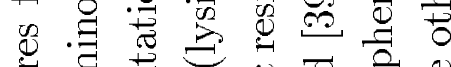

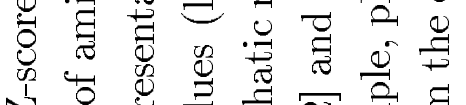
N

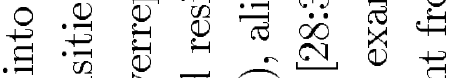

षै

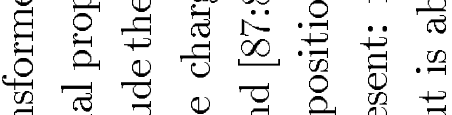

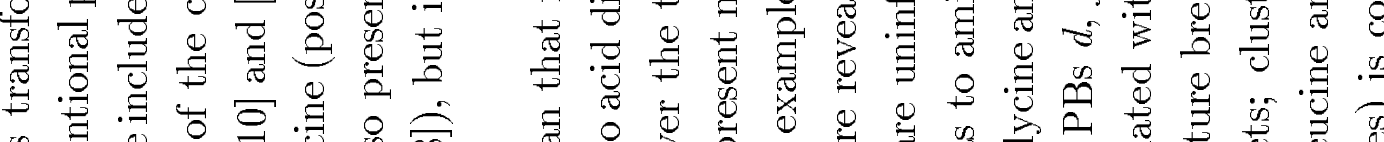

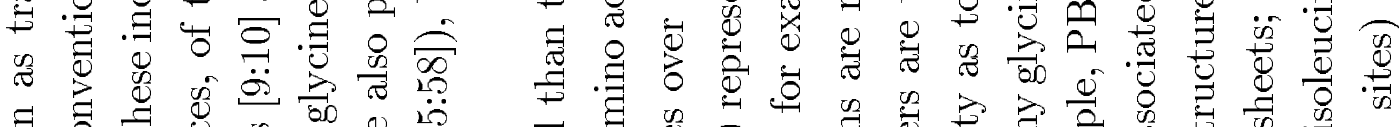

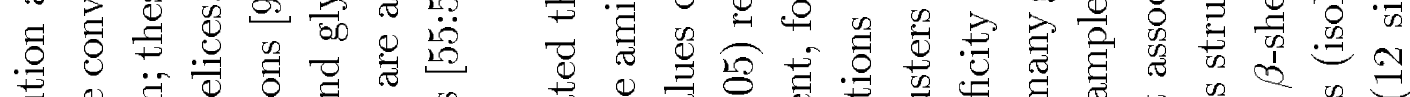

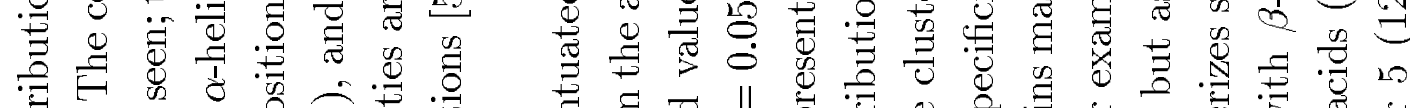

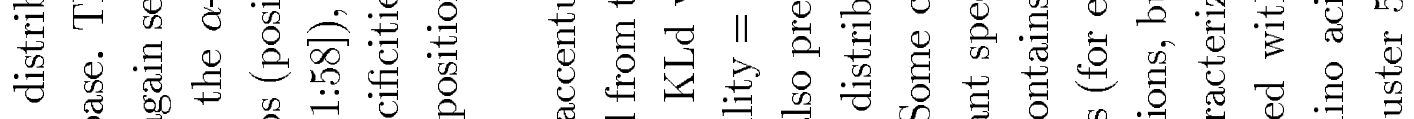

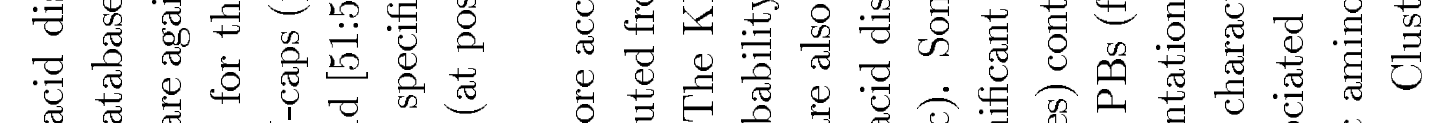

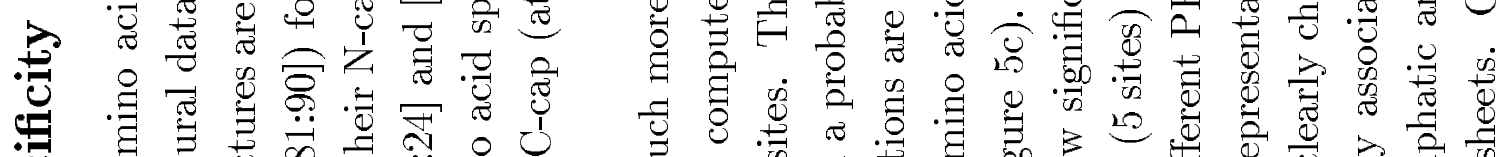

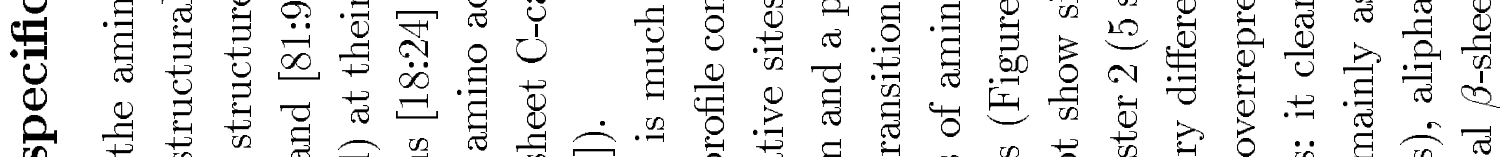

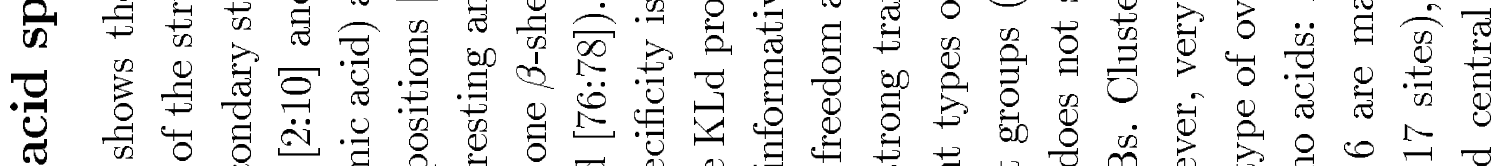

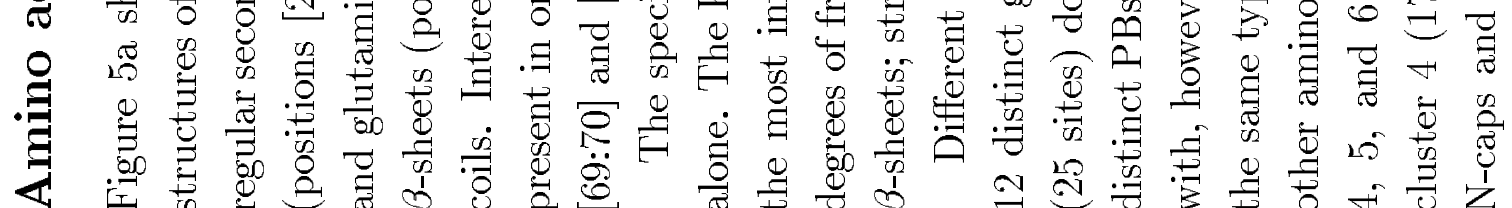




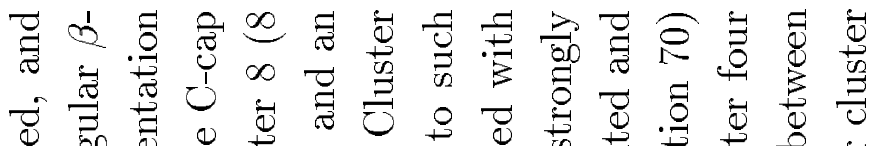

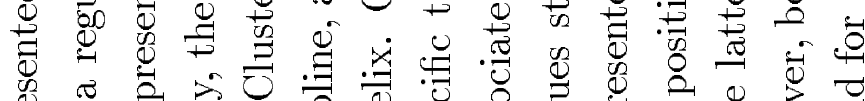

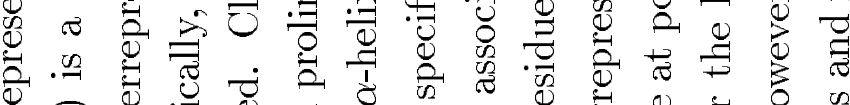

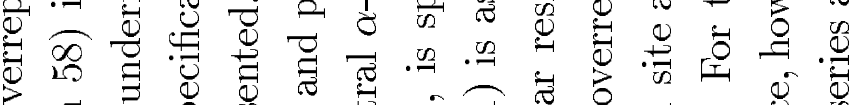

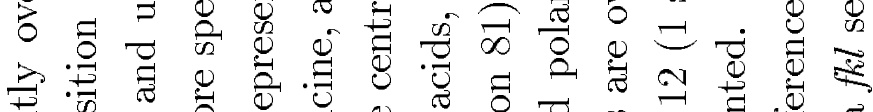

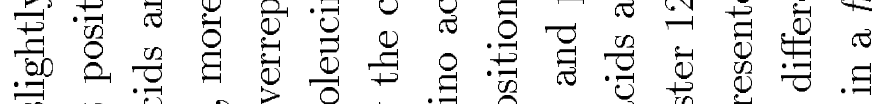

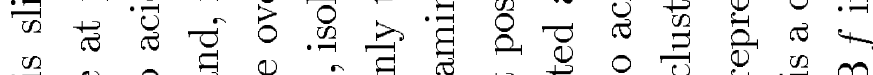

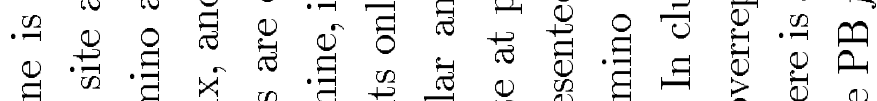
寻

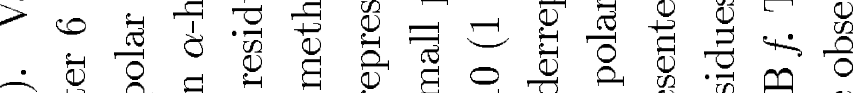

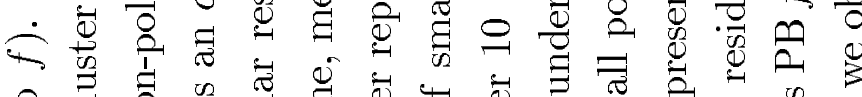

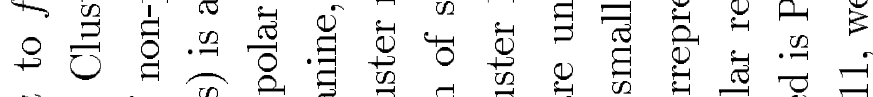
- ต 总

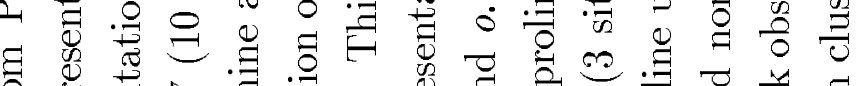

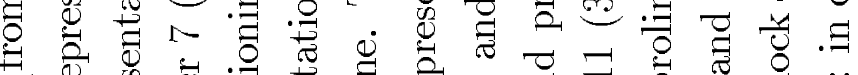

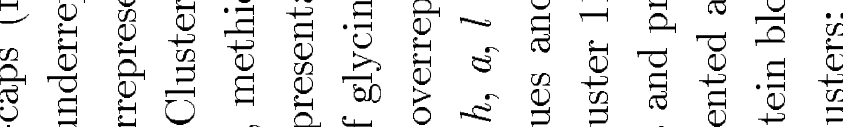

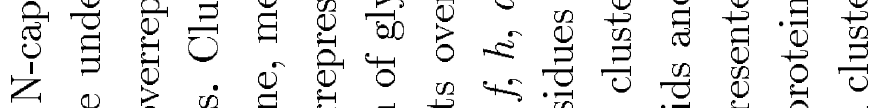

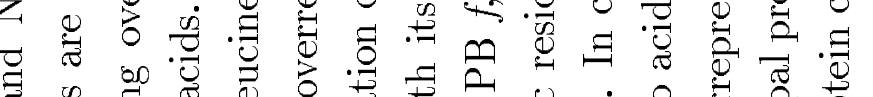

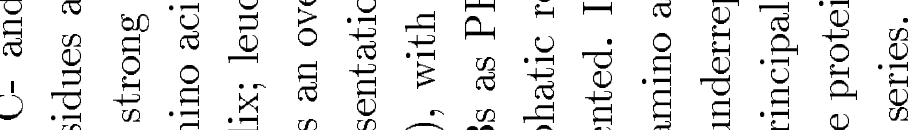

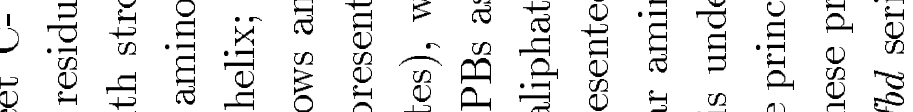
息焉 官

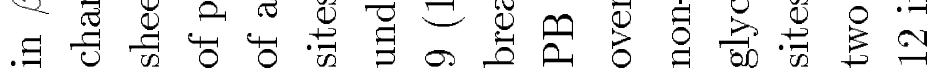

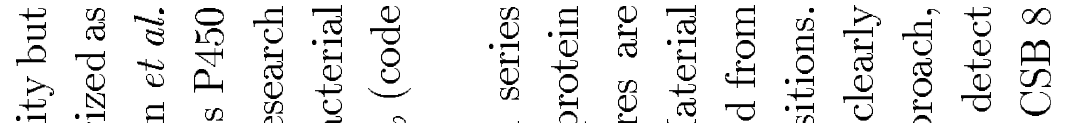

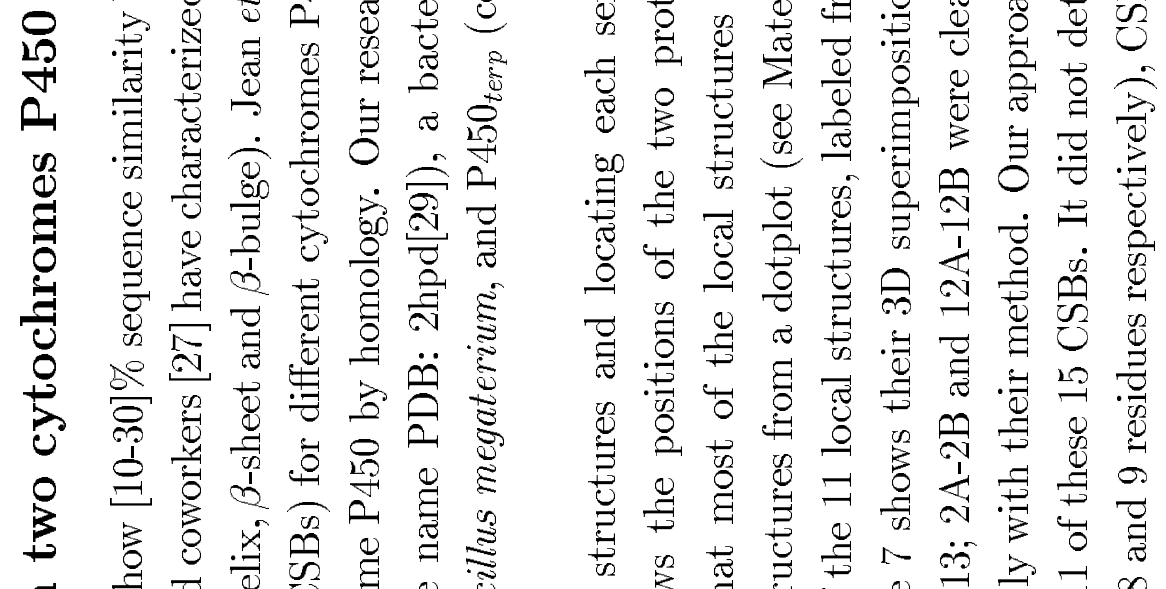

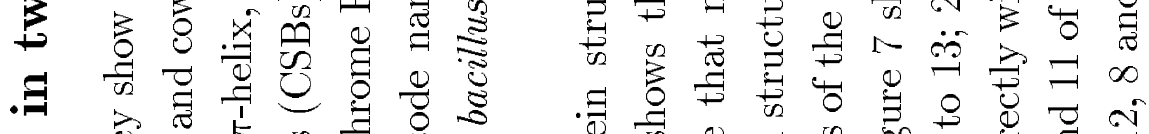

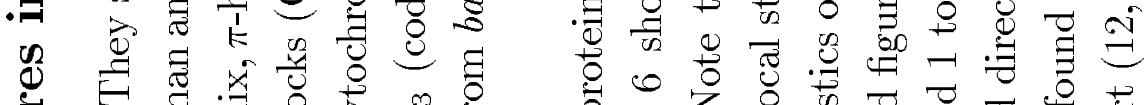
当

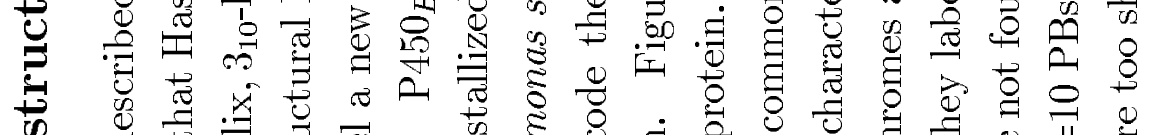

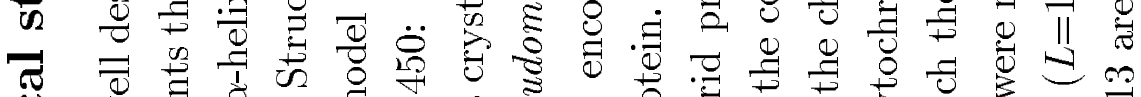

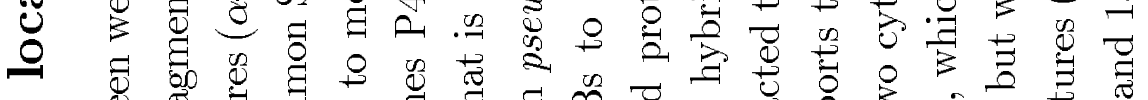

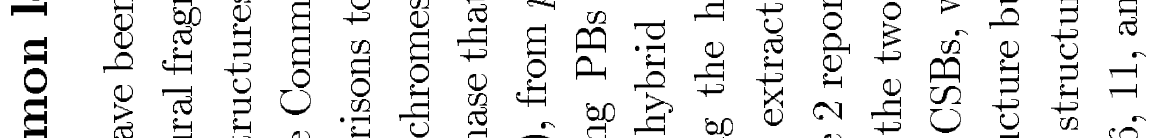

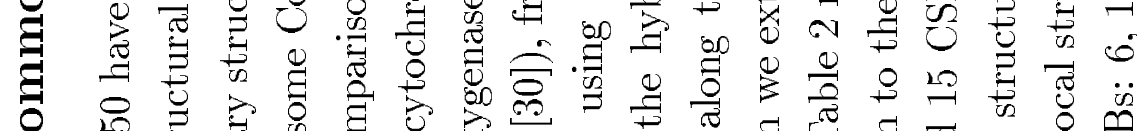

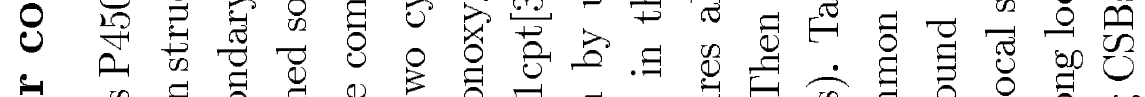

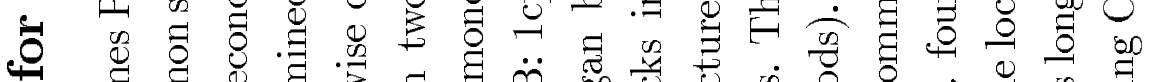

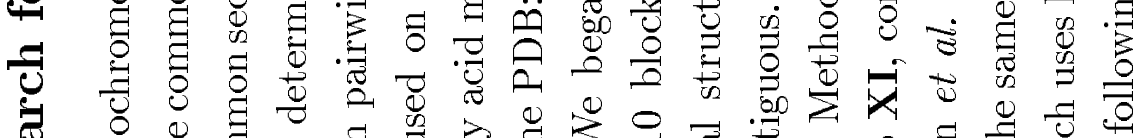

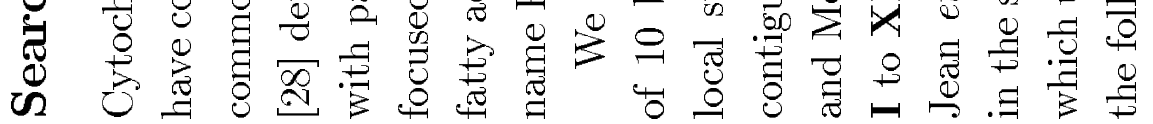




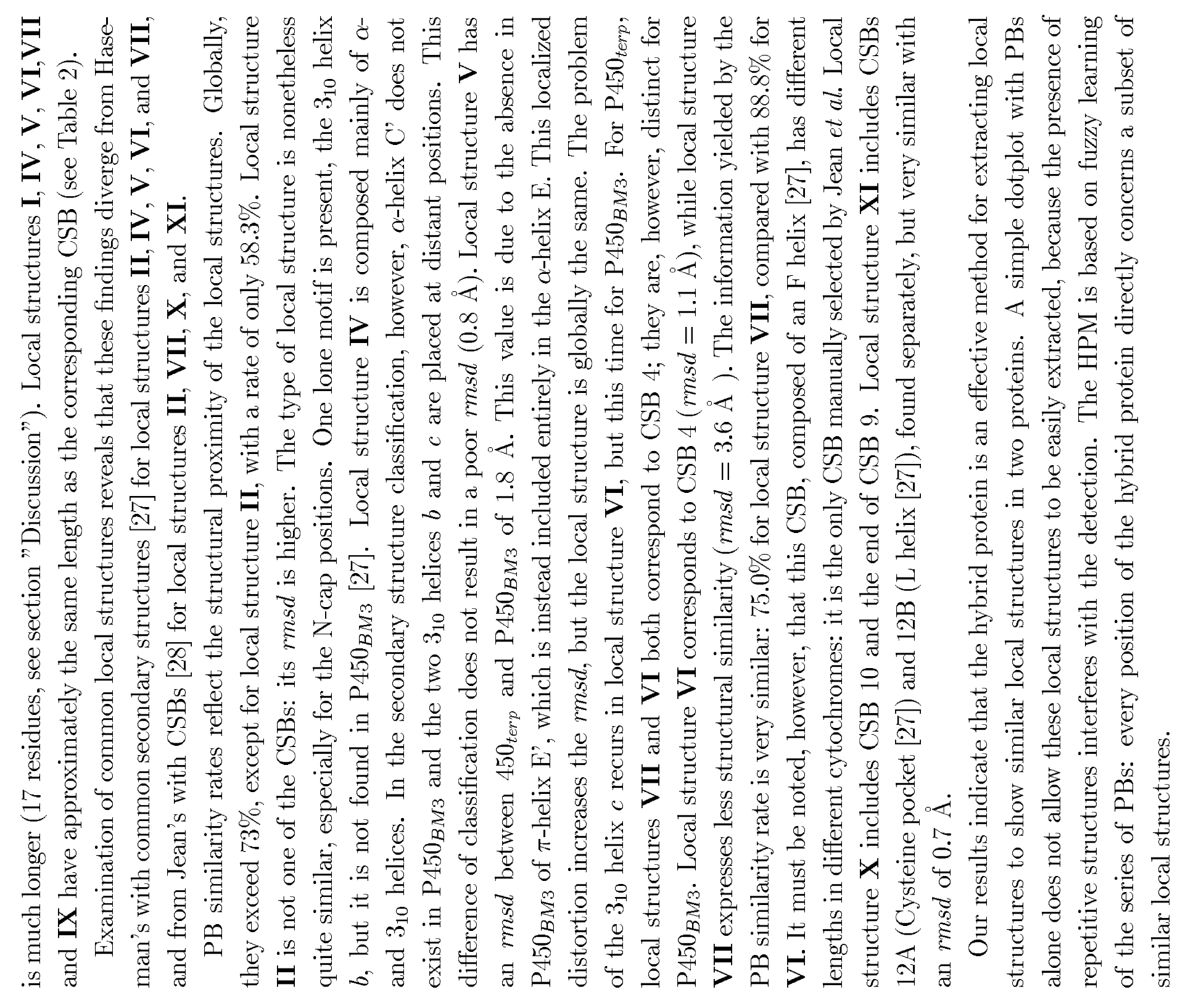


WhIn

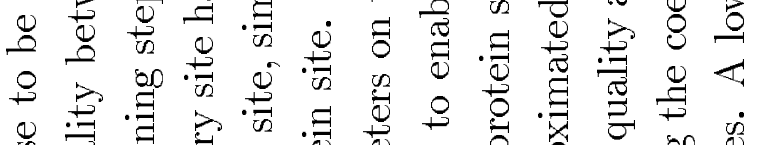
IUnM minn

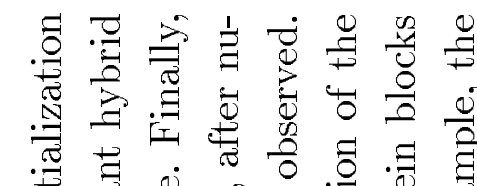

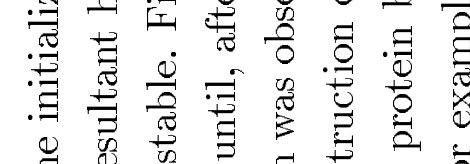

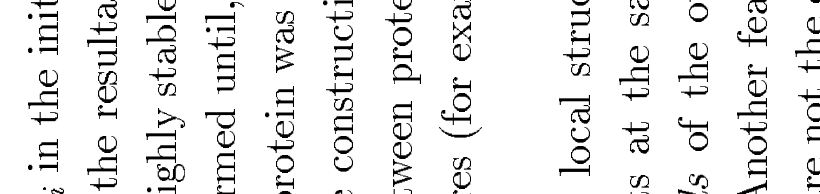

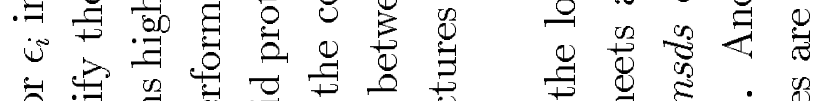

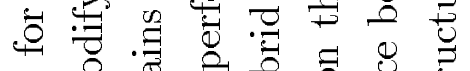

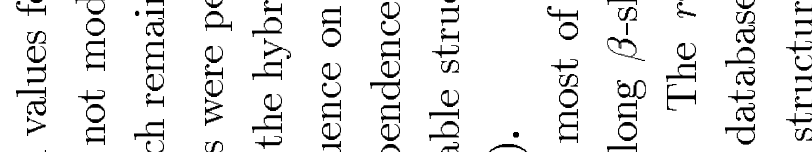

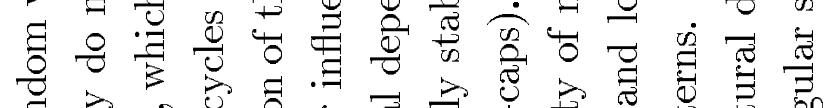

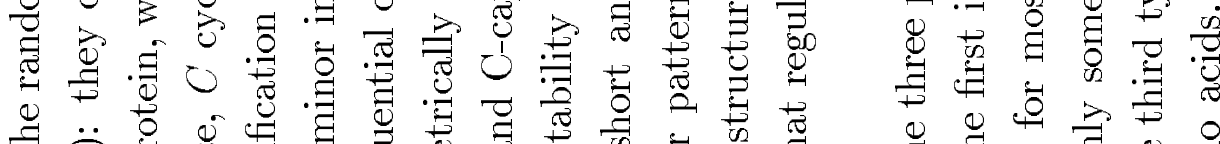

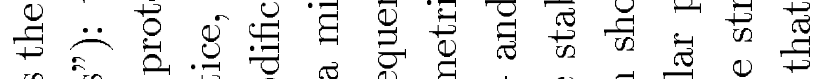

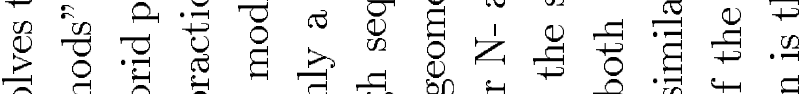
索

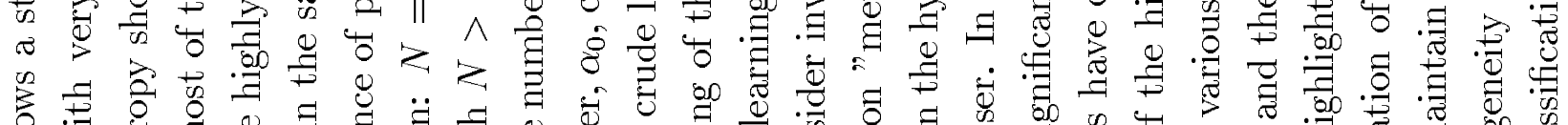

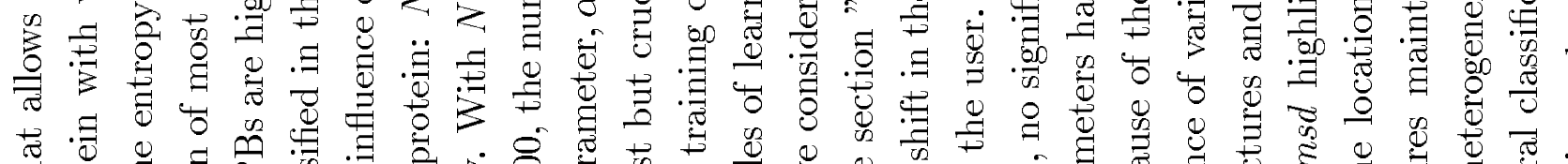

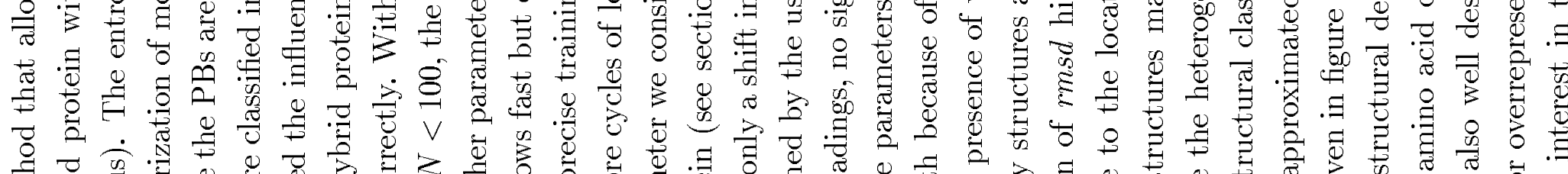

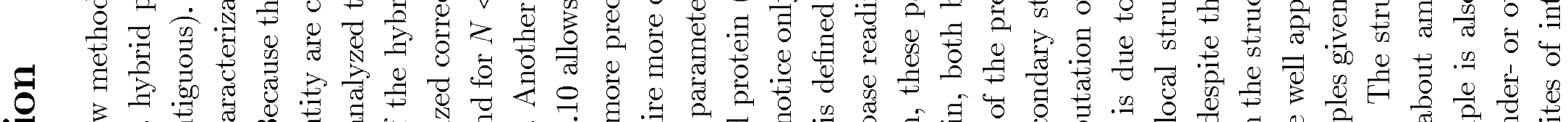

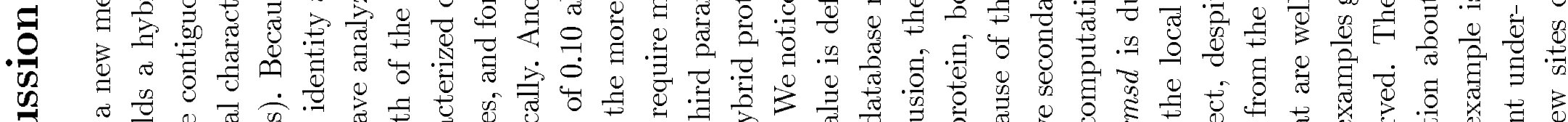

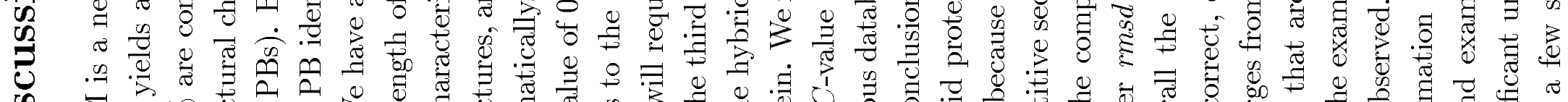

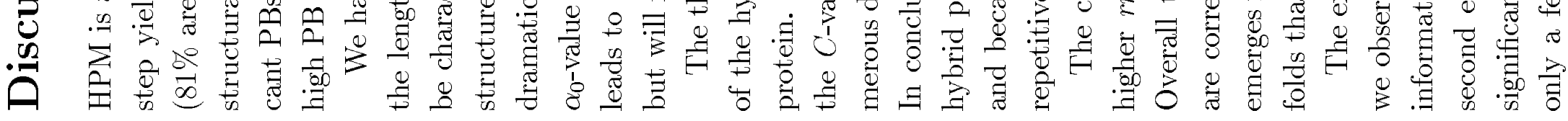




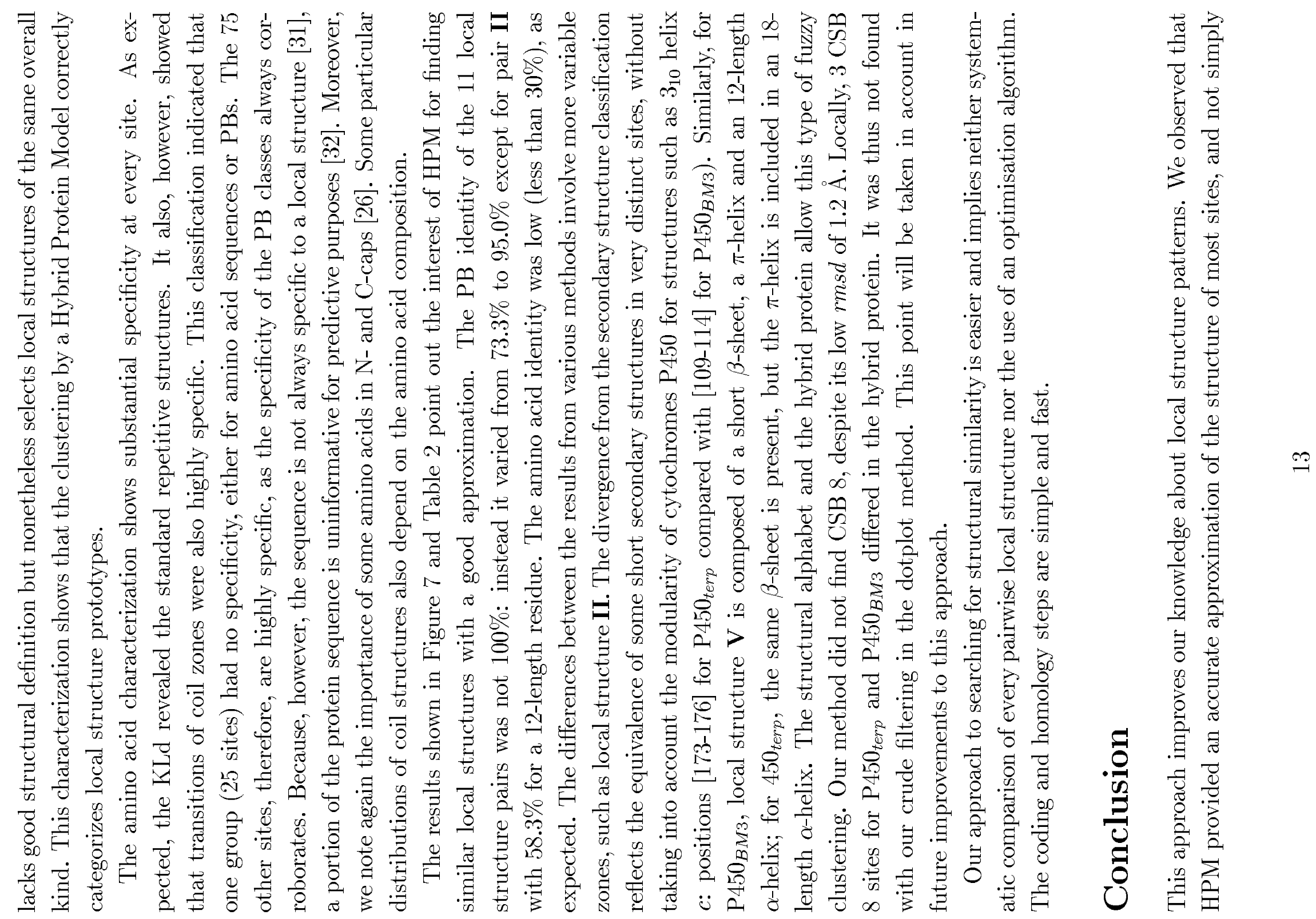




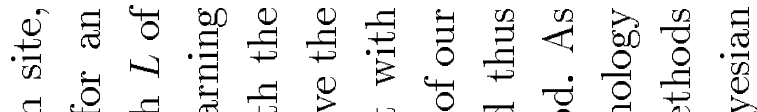

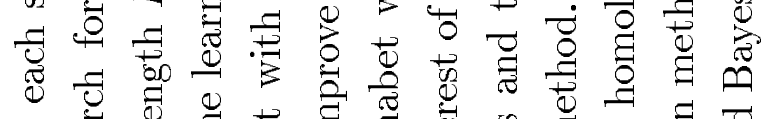

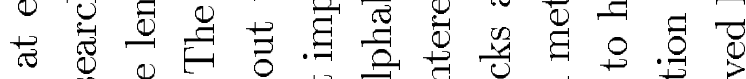

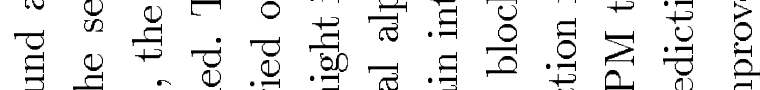

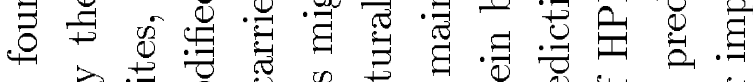
๑

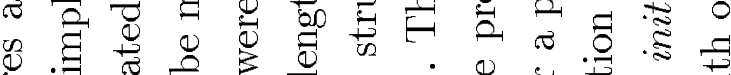

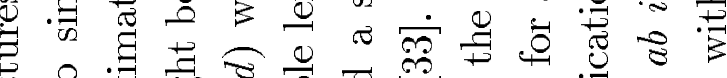

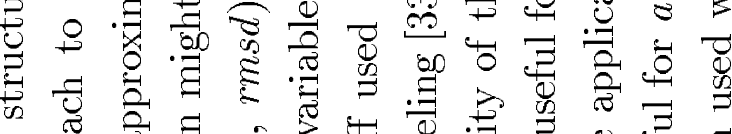

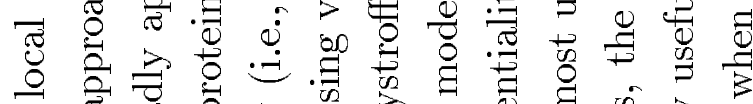

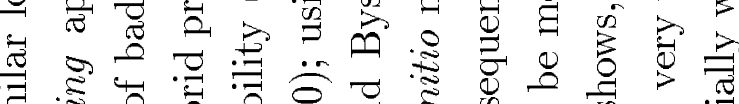

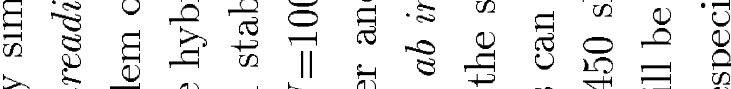

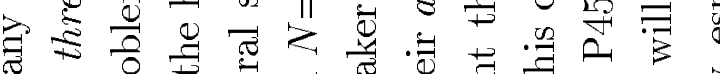

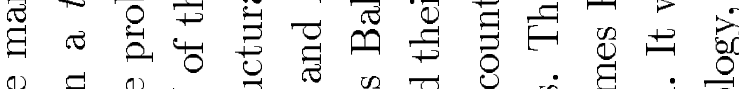

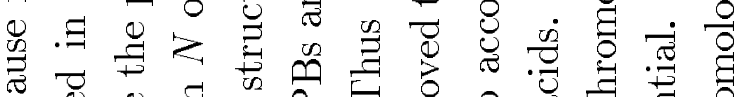

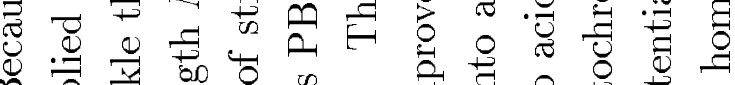

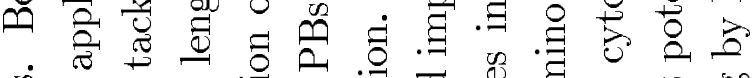
ఏ。

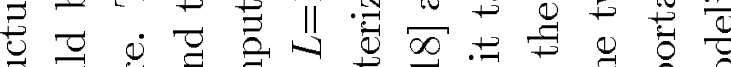
竝

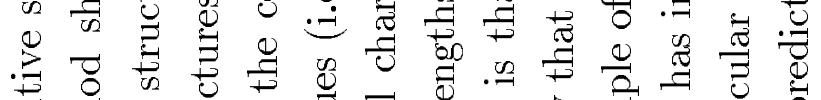

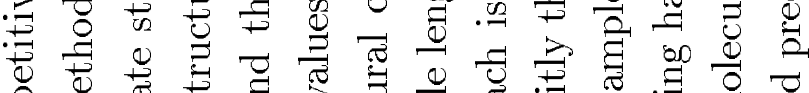

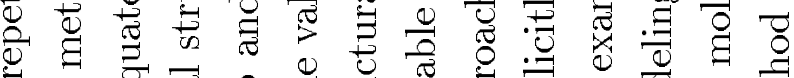

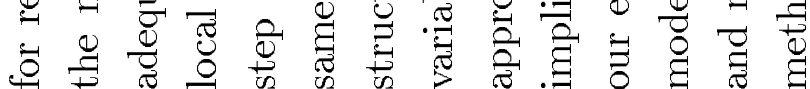

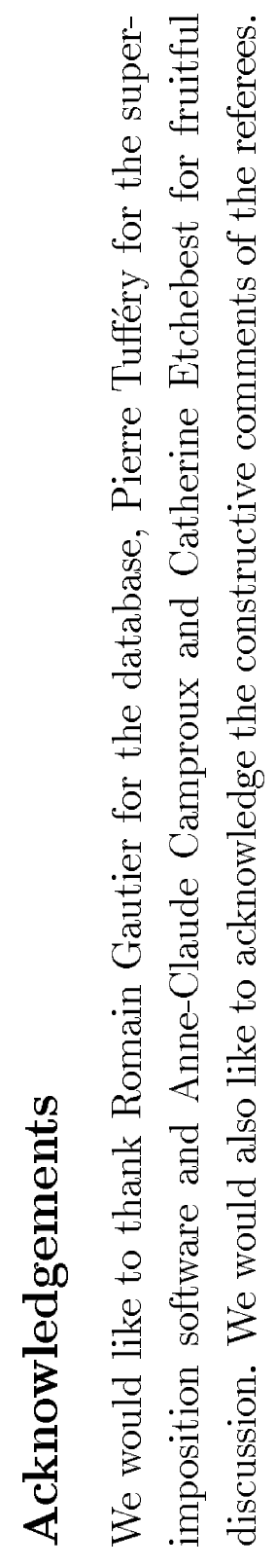

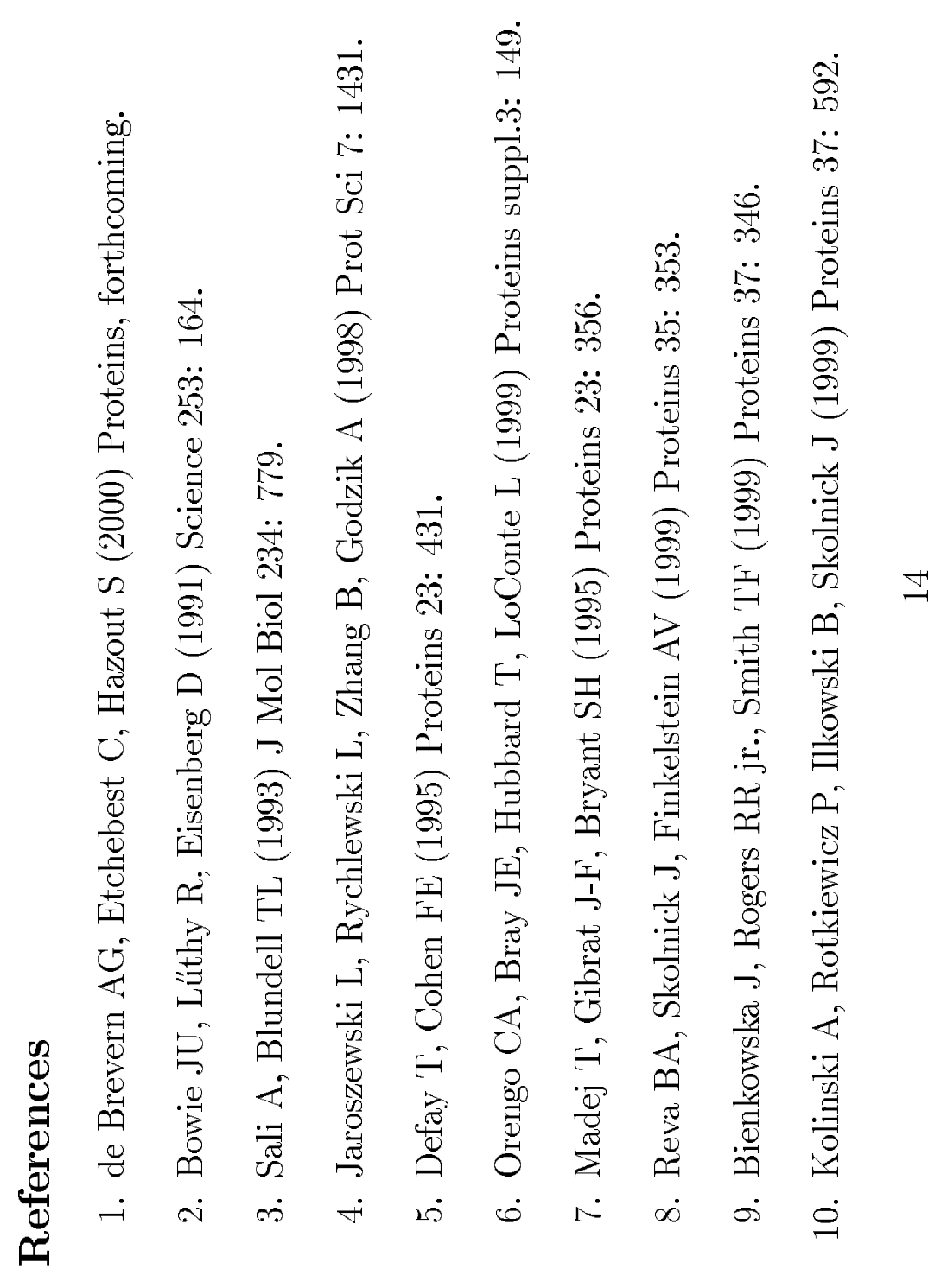




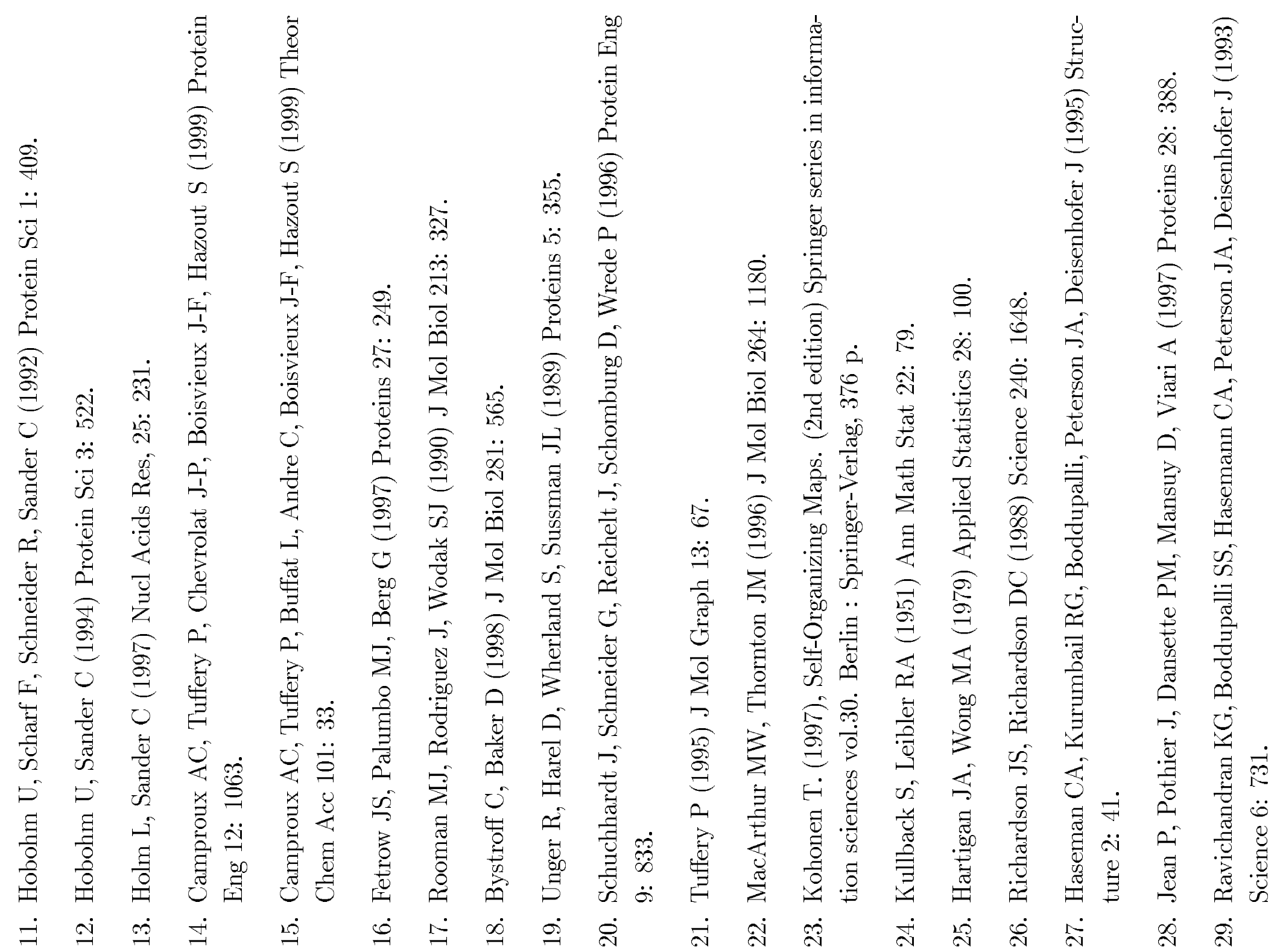




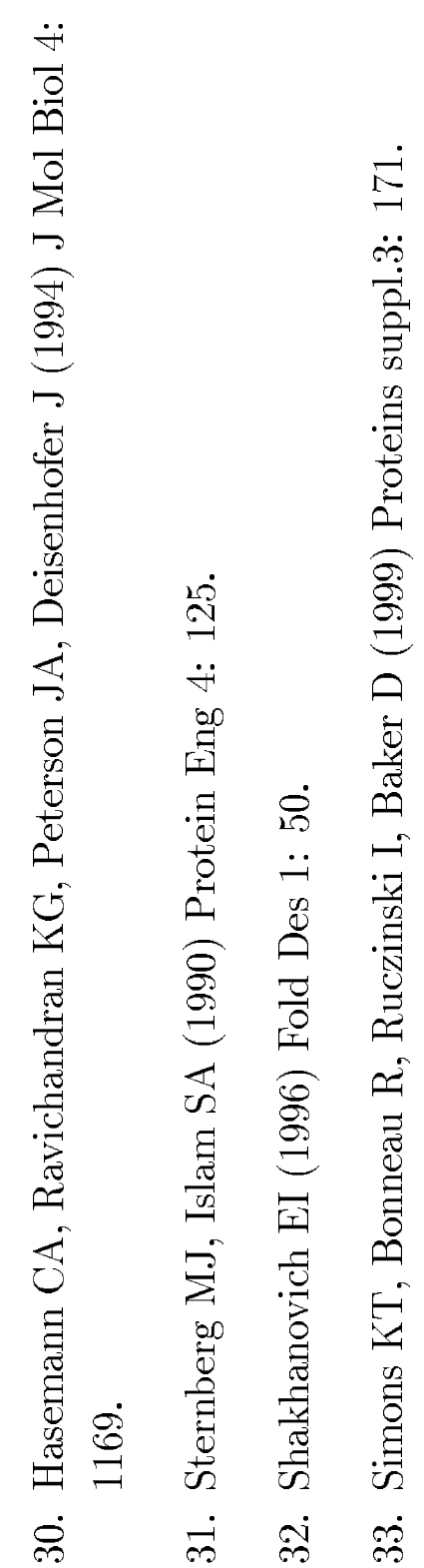

